NBER WORKING PAPER SERIES

\title{
A TEAR IN THE IRON CURTAIN: THE IMPACT OF WESTERN TELEVISION ON CONSUMPTION BEHAVIOR
}

\author{
Leonardo Bursztyn \\ Davide Cantoni \\ Working Paper 20403 \\ http://www.nber.org/papers/w20403
NATIONAL BUREAU OF ECONOMIC RESEARCH
1050 Massachusetts Avenue
Cambridge, MA 02138 \\ August 2014
}

Previous drafts of this paper have been circulated under the title "Clueless? The Impact of Television on Consumption Behavior." We are grateful to Philippe Aghion, Alberto Alesina, Stefano DellaVigna, Nicola Fuchs-Schündeln, Matthew Gentzkow, Larry Katz, David Laibson, Yona Rubinstein, Andrei Shleifer, Nico Voigtländer, Romain Wacziarg, and Noam Yuchtman for helpful comments, as well as seminar audiences at the EEA Annual Meeting, the NBER summer institute, and at Harvard, Heidelberg, HU Berlin, Linz, LSE, UCLA, U Penn, and UPF. We thank Tobias Hauck and Maximilian W. Müller for excellent research assistance; Hans-R. Günther for letting us access the archives of the IM Leipzig; Jeff Blossom for sharing his GIS expertise with us; and Patrick Rothe for professional support with the German income and expenditure survey data. Parts of this research were completed while Davide Cantoni was visiting the University of Heidelberg. We appreciate the financial support of the Paul M. Warburg funds. The views expressed herein are those of the authors and do not necessarily reflect the views of the National Bureau of Economic Research.

NBER working papers are circulated for discussion and comment purposes. They have not been peerreviewed or been subject to the review by the NBER Board of Directors that accompanies official NBER publications.

(C) 2014 by Leonardo Bursztyn and Davide Cantoni. All rights reserved. Short sections of text, not to exceed two paragraphs, may be quoted without explicit permission provided that full credit, including (c) notice, is given to the source. 
A Tear in the Iron Curtain: The Impact of Western Television on Consumption Behavior Leonardo Bursztyn and Davide Cantoni

NBER Working Paper No. 20403

August 2014

JEL No. D12,E21,Z10

\begin{abstract}
$\underline{\text { ABSTRACT }}$
This paper examines the impact of exposure to foreign media on the economic behavior of agents in a totalitarian regime. We study private consumption choices focusing on former East Germany, where differential access to Western television was determined by geographic features. Using data collected after the transition to a market economy, we find no evidence of a significant impact of previous exposure to Western television on aggregate consumption levels. However, exposure to Western broadcasts affects the composition of consumption, biasing choices in favor of categories of goods with high intensity of pre-reunification advertisement. The effects vanish by 1998 .
\end{abstract}

Leonardo Bursztyn

Anderson School of Management

University of California, Los Angeles

110 Westwood Plaza, C 513

Los Angeles, CA 90095

and NBER

bursztyn@ucla.edu

Davide Cantoni

Seminar für Wirtschaftsgeschichte

University of Munich

80539 Munich

Germany

Davide.Cantoni@econ.lmu.de 


\section{Introduction}

In 1980 , over $60 \%$ of the countries in the world were ruled by autocratic regimes; as of 2010 , this number has decreased to $27 \%$. Still, this number is sizable, and it includes some of the more populous countries of the world such as China or Iran (Polity IV, 2010). ${ }^{1}$ In many of these countries, not only individuals' choice sets are restricted, but also their information sets, since non-democratic regimes often limit access to outside sources of information. Indeed, recent history provides several episodes of non-democratic regimes restricting access to foreign, independent media, such as the current censorship of internet content in China (the "Great Firewall"), as well as instances in which foreign governments attempt to broadcast news and information to countries where the free flow of information is controlled, such as Radio Free Europe. Although autocratic regimes generally attempt to seclude their citizens from this information, oftentimes there are cracks in the walls-physical or digital—erected. Does the information that passes these cracks matter?

We focus on a particularly important element that is often constrained in totalitarian regimes: individuals' ability to fulfill their desires of material consumption. Consumption is not only one of the most fundamental economic decisions but it is also a defining feature of the Western way of life. ${ }^{2}$ The destabilizing effects of the desire for higher levels of material consumption have been observed across a variety of totalitarian regimes and can, of course together with the wish for personal freedom and civil liberties, be seen as one of causes of the breakdown of the socialist system. ${ }^{3}$

This paper considers how former exposure to foreign television during a communist regime later translated into differences in private consumption. To study this issue, we exploit a natural experiment: the differential access to West German television broadcasting in East Germany (the German Democratic Republic, henceforth GDR) during the communist era. Whereas most East Germans could (and, according to all available evidence, enthusiastically did) watch West Ger-

\footnotetext{
${ }^{1}$ Cf. Marshall et al. (2010). Regimes with a Polity IV score of -10 to -6 are classified as "autocratic."

${ }^{2}$ Adam Smith famously wrote that "[c]onsumption is the sole end and purpose of all production" (Smith 1776, Bk. IV, ch. 3, pt. 3).

${ }^{3}$ On the role of consumption shortages in East Germany, see Schneider (1996) and Kaminsky (2001). On (Western) television stoking consumption desire in former Yugoslavia, see Pušnik and Starc (2008). More recently, increasing levels of consumerism and craving for capitalistic status symbols have been observed in North Korea: Frank (2010), Frank (2012, pp.40-41), Lankov (2013), Economist (2013).
} 
man TV channels, the inhabitants of some regions of the GDR were not reached by West German broadcasts. Those inhabitants, while equally endowed with TV sets, were only able to watch the East German TV channels, a drab mixture of political propaganda and Soviet-produced movies. We look at the individuals with access to West German TV broadcasts in former East Germany as the treatment group of an "experiment" of having been exposed to Western television for over three decades.

The regions of GDR without access to Western television broadcasts were located either in the northeastern or in the southeastern corner of the country (see Figures 1 and 3). These regions, which together made up for approximately one tenth of the East German population, were either too distant from the Western border or West Berlin, or located in valleys behind mountains that would block TV broadcasting signals. ${ }^{4}$ An example is the large and important district of Dresden, situated in the Elbe valley, which became popularly known as the "valley of the clueless" (Stiehler, 2001).

Empirically analyzing behavior in totalitarian regimes is notoriously difficult due to data limitations. Both official national statistics and survey data are of questionable quality, and revealed preferences are difficult to observe given the restrictions citizens are subject to. In order to examine actual consumption behavior, we look at the period immediately following the German reunification of 1990. Prior to that event, any differences in desired consumption choices between individuals exposed or not to Western TV could not be reflected by differences in consumption behavior, as the goods seen on West German TV were not available in communist East Germany. Consumption in the GDR was strictly regimented by the central planning operated by the Ministry of Commerce and Provisioning; consumption patterns would be determined by the day-to-day availability of goods in store. However, after reunification, this obstacle was no longer impeding the consumption of desired goods by East Germans; any good that had been previously seen on TV could now, at least in theory, also be purchased in East Germany. ${ }^{5}$

We assess the impact of long-term Western television exposure on consumption by analyzing

\footnotetext{
${ }^{4} \mathrm{~A}$ confounding factor that could presumably also affect post-reunification consumption patterns in these regions is their distance from West Germany, which could conceivably have made some Western products less likely to be available for purchase. We address this concern in our analysis, by explicitly taking into account distance to the West German border in some regression specifications.

${ }^{5}$ Moreover, West German broadcasts were available in all regions of former East Germany already in 1990.
} 
the first two waves of the German income and expenditure survey (EVS) collected after 1990. We find important effects of previous exposure to Western television on consumption behavior. The effects are subtler than a simple change in total consumption or household savings. Indeed, we find no evidence of significant and quantitatively meaningful effects of West German TV on those aggregate variables. Our analysis indicates, instead, that Western television affected the composition of consumption via one of its key elements: advertisements. If changes in the composition of consumption are to be attributed to West German television, we should expect larger differences between regions exposed or not to Western television to occur in the consumption of categories of products with higher intensity of advertisement on West German television. ${ }^{6}$ We combine the EVS data with information about the average intensity of advertising of different categories of goods on the main West German TV channel during the last decade before reunification.

We find that previous exposure to Western television affects the composition of consumption shortly after reunification, according to the intensity of pre-reunification West German TV advertisement in different categories of goods: individuals with access to Western television spent significantly more on goods with high intensity of pre-reunification advertisement. Spending on a category of goods that had one more minute of advertising per day during the 1980s was 1.5\% higher in parts of East Germany that had the chance to watch these advertisements, relative to the "untreated" part of East Germany.

We also provide more than just cross-sectional evidence by analyzing also the second postReunification wave of the EVS survey. Our measured effects vanish through time, and are no longer visible in 1998. Our results are robust to: (i) variations in the definition of the exposure to treatment, West German television; (ii) restricting the sample to areas surrounding the threshold for television signal availability (in the spirit of a regression-discontinuity design); (iii) controlling for distance to West Germany and its interaction with intensity of advertisement (to rule out alternative explanations of our findings based on remoteness factors).

Related to our paper by also exploiting the same, sharp change in regime, is the work by Alesina and Fuchs-Schündeln (2007), which analyzes the impact of several decades of exposure to

\footnotetext{
${ }^{6}$ Other factors associated with access to Western television could also potentially affect the composition of consumption, such as exposure of goods in TV shows, movies, etc. We focus on the advertisement mechanism.
} 
Communism on former East Germans' preferences for redistribution and state intervention. Our paper, however, focuses on comparisons within East Germany, as opposed to comparisons between East and West Germans. Burchardi and Hassan (2011) show that West German regions that had a large fraction of households with social ties to the East exhibited higher growth in income per capita in the early years after German reunification. Friehe and Mechtel (2012) provide evidence indicating that after the German Reunification, individuals in former East Germany spent more resources on visible goods than former West German individuals did. Finally, similarly to our research design, the paper by Kern and Hainmueller (2009) uses within-East Germany variation to analyze the effect of exposure to Western media on reported support for the communist regime, using survey data on stated preferences.

This paper also relates to the recent empirical literature that studies media effects, and particularly the effect of exposure to television. A series of papers look at political outcomes: Enikolopov et al. (2011) consider independent TV stations and their effect on the 1999 Russian elections; DellaVigna and Kaplan (2007) report important effects of Fox News on Republican vote shares. DellaVigna et al. (2011) focus on effects of exposure to radio, and report the unintended effects of Serbian radio on the likelihood to vote for extreme nationalist parties in Croatia. Gentzkow (2006) finds a large impact of the expansion of television between 1940 and 1972 on voter turnout. Gentzkow and Shapiro (2004) document that television viewership in Muslim countries changes attitudes towards the West. Another set of research papers considers social outcome variables. Jensen and Oster (2009) document how access to cable TV changed the perception of women's status in India, whereas Olken (2009) tests Putnam's (2000) hypothesis that television decreases social capital by studying the effect of exogenous variation in TV signal availability on Indonesian islands. La Ferrara et al. (2012) report that exposure to television soap operas decreases fertility in Brazil. ${ }^{7}$ Our paper adds to this literature by providing evidence of the effect of exposure to Western television on one of the most fundamental economic decisions: consumption.

Finally, our paper also contributes to the economics literature on advertising. ${ }^{8}$ First, our unique

\footnotetext{
${ }^{7}$ A series of recent papers have also analyzed the effects of other types of media, such as newspapers (e.g., Gerber et al., 2009, Chang and Knight, 2011, and Snyder and Strömberg, 2008) and radio (e.g., Strömberg, 2004 and YanagizawaDrott, 2010). For an overview on media effects, see DellaVigna and Gentzkow (2010).

${ }^{8}$ On the theoretical side, see the different treatments by Dixit and Norman (1978), Becker and Murphy (1993), Nelson (1974), Milgrom and Roberts (1986), Benhabib and Bisin (2002). For an extensive review of the economics literature on
} 
empirical setting provides novel insights on the long-run, overall effects of advertising on consumer behavior. This stands in contrast to the existing marketing literature on advertising, which is usually concerned with marginal effects of small changes in exposure to advertising, e.g. in the context of cable-split experiments for TV commercials, and usually studies shifts across brands, rather than broad categories of consumption goods. ${ }^{9}$ Second, empirical analyses of the effects of advertising are often made difficult by the scope for reverse causality, as advertising is generally targeted towards a given kind of audience (see, for example, Avery et al., 2007). Our paper provides an empirical setting that allows for a well-identified analysis of the causal impact of longterm exposure to advertising on consumption behavior. This is because the East German that could watch West German TV were not, by any means, the targeted audience of the advertising, which reduces concerns regarding endogeneity of the exposure to TV commercials.

Our findings suggest that advertising changes consumption patterns and that its effect is more than just to induce individuals to switch across brands of the same good. Advertising induces a recomposition of consumption across broad categories of goods, depending on the amount of advertising for each category. However, we do not find any evidence in favor of a shift of total levels of consumption expenditures; this runs counter to the argument that advertising may increase aspirations and consumption desires (Galbraith, 1958; Schor, 1998; Baker and George, 2010). ${ }^{10}$

The paper proceeds as follows. In the next section, we provide a brief account of the historical background. In section 3, we introduce our empirical setting, explaining the conditions under which inference of causal effects is possible. Section 4 turns to the actual analysis of consumption data in the light of television access and advertising intensity. Section 5 concludes.

advertising, see Bagwell (2007).

${ }^{9}$ See, for example, the meta-analyses by Hu et al. (2007), Wind and Sharp (2009), or Sethuraman et al. (2011).

${ }^{10}$ The long-run nature of the effects of advertising observed in our data relate this paper to the recent findings by Bronnenberg et al. (2011), who provide evidence of long-run persistence of brand preferences in the US. 


\section{History}

\subsection{East German History}

Following World War II, Germany was separated into four different occupation zones, roughly corresponding to geographical convenience for the allied powers. While the three Western zones (American, British, and French) united economically and politically to form the Federal Republic of Germany (FRG) in 1949, the Soviet occupation zone took a separate path, transforming itself into the German Democratic Republic (GDR), a socialist economy firmly linked with the Soviet Union and the other countries of the Warsaw Pact. The Western exclave of West Berlin, de facto a part of the FRG, was surrounded by GDR territory and was separated from it by the Berlin Wall.

Reunification occurred rather quickly and, by most accounts, unexpectedly, following the historical events of the fall of the Berlin Wall in November, 1989. Economic unification was completed by July, 1990, and the political union of the two halves occurred in October, 1990. The German Democratic Republic was at the time of its fall the most advanced economy in the Warsaw Pact, but was nonetheless decrepit by Western standards, with a barely competitive industrial structure, severe deficiencies in the production and distribution of goods, and burdened with a high level of external debt, required to keep the living standards of East Germans high (Sinn and Sinn, 1992).

\subsection{Television in the GDR}

The main public TV networks from West and East Germany, ARD and DFF respectively, began their broadcasts in the same year, 1952. By that time very few East Germans owned a TV set. However, television gained popularity rapidly, and by the end of 1958, there were already over 300,000 TV sets in the GDR. Based on reports from surveys (Müller, 2000), by 1989 an estimated 98\% of households in East Germany had a TV set, and 46\% a color TV. By 1988, 1 out of 6 households had more than one TV set, leading to an average of 117 TV sets per 100 households. The two production facilities for TV sets in East Germany were located in Dresden and in Staßfurt (in the district of Magdeburg).

East German TV (DDR-FS) was severely controlled by the communist party and this explained its low acceptance in the population. Its broadcasts were not considered a serious news source; 
where possible, GDR citizens turned to Western media both as a source of information, and to enjoy the better quality of entertainment programs. There was no advertising on East German TV until shortly before Reunification. After the events of November 1989, the GDR's grip on the state media became weaker. DDR-FS became almost completely separate from the state apparatus, starting a number of new program strands, including free and open debates. Upon reunification on 3 October 1990, DDR-FS ceased to be the state broadcaster of the former GDR. Its frequencies were taken over by Western Germany's main public TV channel, ARD, on 15 December 1990 (Claus, ed, 1991).

\section{Empirical Setting}

\subsection{Treatment definition}

Our definition of the "treatment" area is based on the availability of signal from the West German TV stations. West Germany had two main public TV stations at the end of the 1980s, ARD and ZDF. Those stations were able to reach East German viewers through terrestrial broadcasting (over-the-air), as a chain of very powerful antennas was located along the FRG-GDR border and in the exclave of West Berlin. Anecdotal evidence about the availability of Western TV signal (Kern and Hainmueller, 2009, pp. 382, 392) suggests that the areas with worst coverage were indeed in the northeast and the southeast of the GDR. ${ }^{11}$

We improve on this evidence by calculating the actual availability of Western TV signal in the GDR based on a signal propagation model. In the absence of any obstacles (air, clouds, terrain), an electromagnetic signal declines in strength with the square of the distance from its source. In practice, the actual availability of TV signal depends on a variety of factors. Signals can be refracted by mountains and reach their destination even if no direct line-of-sight exists between sender and receiver. To obtain a measure of actual TV signal availability, information about the distance to the signal source has to be combined with information about the Earth's curvature and elevation features of the terrain. ${ }^{12}$ We use the irregular terrain model (ITM, version 1.2.2; Hufford,

\footnotetext{
${ }^{11}$ Private television in Germany was in its beginnings around 1990, and was broadcast mainly via cable.

${ }^{12}$ In addition, day-by-day variation in the quality of TV signal is given by atmospheric conditions; a particular phenomenon of extended signal range, known as tropospheric propagation, can occur in concomitance with temperature
} 
1995), which was created for the needs of frequency planning in television broadcasting in the United States in the 1960s. The ITM model is implemented by the ArcGIS Extension CSPT VHF.

To apply the ITM to the case of East Germany, we collected information about all antennas used to broadcast the main public TV station in West Germany, ARD (Norddeutscher Rundfunk, ed, 1989). ${ }^{13}$ Table A.1 in the Supplemental Appendix lists the antennas in use in 1989, with their respective heights, power, and frequency of transmission; Figure 1 displays the results of our analysis. TV signal strength (at $10 \mathrm{~m}$ above ground) is calculated for the whole territory of the former GDR, divided into a raster of $1 \times 1 \mathrm{~km}$. We then calculate the average level of TV signal strength for each municipality, based on this raster; these values range from $-107 \mathrm{~dB}$ in Sassnitz on the island of Rügen (northeast of the GDR) to $-10.9 \mathrm{~dB}$ in Seeburg, on the border to West Berlin.

\section{[Figure 1 about here]}

As discussed above, for a given set of transmitters, the quality of TV signal can still vary considerably depending on atmospheric conditions and on the power of the receiving antennas. However, whereas above a certain level of signal strength the quality of reception does not vary substantially with signal strength, below a certain threshold-when the noise is stronger than the signal - no reception is possible at all. TV signal quality does not decrease linearly, but discontinuously, with the boundary of the discontinuity varying over time, depending among other things on atmospheric conditions. ${ }^{14}$ To this extent, the discontinuity of TV signal strength is fuzzy.

We operationalize a definition of the treatment area based on the level of signal strength in Dresden: existing anecdotal evidence suggests that, with normal atmospheric conditions and standard TV receiver sets, Dresden was close to the signal strength discontinuity. Only the neighborhoods of Dresden located on hills were able to receive some signal under optimal conditions; the large majority of the city's inhabitants were not able to watch Western TV. To confirm this, we draw on a survey of East German youths conducted in 1985, in which individuals were asked anony-

${ }^{13}$ In the overwhelming majority of East German municipalities, the strength of ARD signals was higher than for ZDF, the second West German public TV station. We therefore focus on ARD availability. We also replicate our analysis using instead ZDF availability and minutes of advertising on ZDF, and the results (available upon request) are unchanged. The correlation in advertising intensity for the analyzed categories for ARD and ZDF is extremely high $(\rho=0.9889)$.

${ }^{14}$ This is analogous to the familiar experience of listening to a radio station while driving a car: sound quality, having been good for a long while, suddenly starts deteriorating, and then fades off completely.
} 
mously how often they would watch Western TV stations. ${ }^{15}$ Even though this survey contains only a rough regional indicator, referring to the district (Bezirk) of residence, the answers show clearly the discontinuity in viewership. While in the district of Cottbus (average signal strength: $-75.9 \mathrm{~dB}$ ) only $1.67 \%$ of respondents declared that they never watched Western TV broadcasts, in the district of Dresden (average signal strength: $-86.3 \mathrm{~dB}$ ) the corresponding figure is $67.85 \%$ (see Figure 2, top panel). The findings are reversed if one considers the percentage of respondents watching Western TV daily (Figure 2, bottom panel).

\section{[Figure 2 about here]}

Given that the average signal strength in the city of Dresden was $-86.8 \mathrm{~dB}$, we consider all municipalities with signal strength equal or below that threshold to be in the control area. The treatment area thus comprises all regions with a positive probability of reception of Western TV broadcasts; note that a part of the households in the treatment area (especially those in the range between -75 and $-86.8 \mathrm{~dB}$ ) probably had no access to Western TV some or even most of the time. The control area is thus constructed such as to comprise only individuals who, with certainty, had no access to Western TV. In doing this, we implicitly hypothesize that all households in the GDR area tried to watch Western TV whenever it was technically feasible, no matter how bad the picture quality. While in contrast to studies that take signal strength as a linear predictor of viewership (Olken, 2009; Enikolopov et al., 2011), this approach is, in our view, justified by the crucial importance of access to Western media in a communist regime, and consistent with actual viewership data as in Figure 2.

The resulting partition of the GDR into treatment and control areas is displayed in Figure 3. This definition of treatment based on the geospatial modeling of signal propagation is very close to the available anecdotal evidence on TV signal availability (cf. Figures 1 and 3 in Kern and Hainmueller, 2009). In our empirical analysis, we show that our results are robust to small variations of the signal availability threshold.

\footnotetext{
${ }^{15}$ Zentralarchiv für Empirische Sozialforschung ZA 6008. This survey was conducted by the East German Institute for Youth Research, Zentralinstitut für Jugendforschung. Due to the comparatively strong anonymity standards that were applied in conducting these surveys, they are generally considered valid sources of information-despite their provenance from an authoritarian regime-by most social scientists (Friedrich et al., eds, 1999; see also Kern and Hainmueller, 2009, p. 381).
} 
[Figure 3 about here]

Alternatively, we also use a continuous measure of treatment, intended to replicate the actual likelihood of Western TV viewership as a function of signal strength. We construct this measure by fitting a (logistic) cdf to the observed viewership patterns of Figure 2, upper panel. The resulting, S-shaped curve (a logistic cdf with parameters $\mu=-84.6$ and $\sigma=2.3$ ) is the best approximation for the share of respondents who never watch Western TV, as a function of signal strength. Our continuous treatment variable, representing the probability of watching any Western TV, is then constructed by subtracting the fitted curve from unity. Figure 4 compares the binary treatment indicator, based on the threshold at $-86.8 \mathrm{~dB}$, and the continuous treatment variable.

\section{[Figure 4 about here]}

\subsection{Conditions for identification}

For the identification strategy to be valid, we need the following four conditions to hold:

Condition 1 The inhabitants in the treatment and control regions were comparable.

While there were certainly patterns of specialization and regional peculiarities across the regions of the GDR, we contend that, crucially for our identification, no substantial differences existed between the treatment and control regions as defined for the purposes of our work, neither before the "treatment" (i.e., the regionally differentiated access to West German media) started, nor right after reunification.

Both regions contained industrial parts, with a fairly high level of technological development and cultural sophistication, such as Dresden in the control, Leipzig and Halle in the treatment; as well as more agricultural and less densely populated parts, such as the control region in the NorthEast around Greifswald, and the districts of Schwerin or Potsdam in the treatment. This is reflected by the social and economic indicators reported in Table 1; these data are drawn from the GDR Statistical Yearbooks of 1955 (the first one published after the war) and 1990. In the Yearbooks, data are aggregated at the level of districts (Bezirk). The districts of Dresden, Neubrandenburg

and Rostock coincided partially with the regions lacking TV reception in the southeastern and 
northeastern corner of the GDR (cf. Figures 1 and 3); we thus consider them as our "control" area, and define the remaining 11 districts as the "treatment" area. ${ }^{16}$

As evident from the comparison in Panel A of Table 1, in the 1955 data at hand the two groups of districts appear virtually indistinguishable with respect to the available variables: population density, shares of employment by sector, sales and savings. Analogous data for 1990, in the last year of the GDR's existence, show a similar picture (Panel B). To check for differential trends between 1955 and 1990 in the two groups of districts, Panel C looks at the differences in the means of the variables between the two years for the two groups. Again, we do not observe any significant differences. ${ }^{17}$

[Table 1 about here]

Condition 2 No selective spatial sorting across treatment regions occurred.

It is important to exclude spatial sorting across treatment regions. If individuals more interested in Western broadcasts and/or more susceptible to Western advertising had moved into the area with better reception, this would mar our identification of causal effects.

Before reunification. In a centrally planned economy such as the GDR, spatial mobility was seriously hampered; the allocation of labor as a factor of production had to follow the overarching social and economic objectives set by the planning committees. Mobility of labor across occupations and across space was therefore considerably lower than in any free-market economy, and was additionally reduced by the serious housing shortages that affected the GDR over the whole 40 years of its existence (Kern and Hainmueller, 2009, p. 387; Grünert, 1996).

Data based on population registries in the years 1970-1990 show that every year only 2.5 out of 100 citizens of the GDR would change their residence (or, equivalently, an average of once every

\footnotetext{
${ }^{16}$ In our baseline analysis we exclude observations from East Berlin. East Berlin was the capital of the GDR, where a large fraction of the state bureaucracy was located, giving rise to different types of privileges to its inhabitants. It was a commonplace before 1990 that East Berlin's residents never had to suffer the shortages so common in the rest of the GDR. Apart from that, the demographic composition of the East Berlin district is highly divergent from the other regions, since it was mainly a city-state, seat of the country's administration, rather than a larger territorial unit. Adding East Berlin would therefore affect the balancedness of covariates across treatment and control areas. In our robustness regressions, we add observations from East Berlin, and our results hold.

${ }^{17}$ In section 4 , we will argue that in the context of the dataset used the treatment and control areas are balanced along a broad array of individual-level observable covariates.
} 
40 years) - a rate of spatial mobility three times lower than the corresponding value for the FRG, a democracy and a free market economy, in the same time interval (Grundmann, 1998, p. 98). Also, when we compare the treatment and control districts both in 1955 and 1990 (Table 1), we do not observe any differential trend for the two groups between 1955 (before Western TV was popular in the treatment area) and 1990 (Panel C). The two regions were very similar along the observable variables, both before and after Western TV became a popular source of entertainment in the treatment area. ${ }^{18}$

Between reunification and the measurement of effects. Migration of random subsets of the populations in the treatment and control regions would attenuate our findings. However, selective migration could potentially be a confounding factor with our estimated effects. Unfortunately, we do not perfectly observe the type of people that migrated out of the control and treatment areas. However, the available evidence suggests that selective migration does not seem to be of concern in our setting. We first look at overall migration in Table 2, which shows that migration rates year by year from treatment and control areas to West Germany were, after a peak immediately after Reunification, comparatively low and, more importantly, statistically similar across the treatment and control regions. ${ }^{19}$ We also provide evidence in Appendix Table A.4 that migration rates from treatment and control regions to West Germany broken down by age intervals were essentially identical for all age groups.

[Table 2 about here]

Condition 3 The individuals in East Germany that could watch West German TV did actually watch it.

Available evidence suggests that this was indeed the case. Despite the inherent danger it would have posed to the stability of the autocratic regime, East German authorities mostly closed

\footnotetext{
${ }^{18}$ Moreover, there is no evidence for directed migration overall from the control to the treatment area. While population declined everywhere in East Germany between 1955 and 1990, the decline was stronger in the treatment area $(-9.86 \%)$ than in the control area $(-6.76 \%)$.

${ }^{19}$ The largest part of East to West migration occurred in 1989 and 1990 (see Hunt, 2006); unfortunately, county-level migration statistics are available only for the years 1991 onwards. In Appendix A.3 we provide more detailed evidence, by analyzing total migration rates from treatment and control areas and the breakdown of these rates by destination (Berlin, West Germany, control region, and treatment region), suggesting that total migration rates were low and similar in treatment and control areas.
} 
an eye on the installation of antennas suitable for watching West German TV channels. The frequencies of West German TV broadcasts were not jammed, either, even though this was technically feasible and practiced in the case of radio stations (Hesse, 1988; Beutelschmidt, 1995). ${ }^{20}$ For instance, a survey of East German youths in 1985 reported that respondents watched on average more than two hours of West Germany TV each weekday. ${ }^{21}$ As we reported in Figure 2 in section 3.1 above, a related survey found that $66.28 \%$ of respondents in districts with access to Western television declared they watched the Western TV stations daily. In contrast, only 5.72\% of the respondents in the district of Dresden declared so. ${ }^{22}$ Survey evidence also suggests that Western media were used in East Germany mainly to watch entertainment shows and their advertisements (Stiehler, 2001; Buhl, 1990; Hesse, 1988).

Moreover, it was not the case that the limited availability of attractive entertainment options and news sources in the areas without Western TV reception prompted households living there to buy fewer TV sets. In fact, classified data from the GDR Ministry of Commerce and Provisioning suggest that, in 1983, the district of Dresden had an above-average density of color TV sets, whereas the districts of Neubrandenburg and Rostock did not differ significantly from the country-wide average in that respect. ${ }^{23}$

Condition 4 The measured treatment effects are driven by product demand differences, and not supply differences.

It is important that our treatment effects reflect differences in demand from the treatment and control areas, and not differences in supply conditions. Since the regions previously not exposed to West German television are also generally far from the border with West German, we need to be sure that we are not capturing a "remoteness effect" that could affect the availability of products in these areas. To address this question, we resort to the Establishment History Panel

\footnotetext{
${ }^{20}$ In 1961, after the construction of the Berlin Wall, East German authorities initially attempted to tear down roof antennas directed toward West Germany. However, the available historical evidence suggests that due to the unpopularity of these measures, the East German regime soon realized that it had no choice but to accept that a very large fraction of East Germans watched West German TV frequently (Kern and Hainmueller, 2009).

${ }^{21}$ Zentralarchiv für Empirische Sozialforschung ZA 6073. Refer also to fn. 15.

${ }^{22}$ Zentralarchiv für Empirische Sozialforschung ZA 6008.

${ }^{23}$ This emerges from a (then classified) report by the Institut für Marktfortschung to the Ministry of Commerce and Provisioning (Ministerium für Handel und Versorgung): "Möglichkeiten einer näherungsweise Ermittlung von bezirklichen Ausstattungs- bzw. Bestandsgrößen," Leipzig 1983. A scan of the report is on file with the authors.
} 
(Betriebs-Historik-Panel, BHP), a 50\% random sample of all businesses in Germany available from the German Institute for Employment Research (IAB). Table 3 compares the number of food supermarkets, mail order companies and other retail stores (expressed in plants per 1000 inhabitants) active in the treatment and control areas in 1993, the first year included in our data analysis of section $4 .^{24}$ The densities of businesses are extremely similar in the two areas and the differences are never statistically significant (the lowest p-value across the three categories is greater than 0.54). In addition to that, in subsection 4.5 we provide evidence that our measured effects are not explained by distance to West Germany.

[Table 3 about here]

\section{Consumption after reunification}

\subsection{The German Income and Expenditure Survey (EVS)}

Prior to the 1990 German reunification, any differences in desired consumption choices between individuals exposed or not to Western television could not be reflected by differences in consumption behavior. Goods seen on West German TV were generally not available in communist East Germany, where consumption was strictly regimented by the central planning operated by the Ministry of Commerce and Provisioning. However, after reunification, such obstacle was no longer preventing the consumption of desired goods by East Germans; any good that had been previously seen on television could now, at least in theory, also be purchased in East Germany.

We therefore focus on the period after reunification to assess the effects of West German television on consumption choices. For that purpose, we turn to the results of the German Income and Expenditure Survey (Einkommens- und Verbrauchsstichprobe, EVS) conducted by the German federal statistical office. These data can help us understand how exactly access to Western TV changed the consumption behavior of East German citizens. Conducted every five years on over 70,000 representative households (approximately 10,000 of which are in our East German subsample), this survey records exact expenditures on a variety of goods over the course of one year.

\footnotetext{
${ }^{24}$ Results based on equivalent data for the years before 1993 are qualitatively similar and available upon request.
} 
Unfortunately, the Einkommens- und Verbrauchsstichprobe is not conducted as a panel, therefore we are not able to estimate the within-household variation during the period. ${ }^{25}$

We use the first two waves conducted after reunification: 1993 and 1998. While 1993 lies already some years after reunification, this is the first available year with data on East Germany. We expect any effects stemming from the differential exposure to Western television before 1990 to be, if anything, still present in 1993, while they might have already faded away by 1998, after eight years of integration into a capitalist system. ${ }^{26}$

Table 4 provides some summary descriptive statistics, divided by treatment status (binary treatment indicator), about the households included in the two waves of the EVS used here. In our regressions, as well as in these summary statistics, we always use the sampling weights provided by the German federal statistical office (selection of households included in the EVS occurs through stratified sampling). The results in Table 4 show how the treatment and control regions are largely similar across most characteristics.

[Table 4 about here]

\subsection{West German TV and aggregate consumption behavior}

Does long-term exposure to Western television affect aggregate consumption behavior? In particular, do individuals exposed to Western television change their levels of total private consumption and savings? Are they more likely to take on consumer credit to finance additional splurges? A certain strand of the social science literature (Galbraith, 1958; Schor, 1998) would suggest that advertising is used by corporations to increase households' aspirations and overall consumption levels.

We thus start our analysis of the effect of long-term exposure to Western television by first

\footnotetext{
${ }^{25}$ For the analyses performed in this section we had to draw on the restricted-use version of the EVS, which records the municipality of residence of each household interviewed. This information is needed to determine the treatment status. Due to confidentiality reasons, this version of the EVS dataset can be accessed only on the premises of the German statistical office (Destatis).

${ }^{26}$ In the context of preferences for redistribution and attitudes about the role of the state in society, Alesina and FuchsSchündeln (2007) find remarkable persistence: according to their estimates it will take about one to two generations for former East Germans and West Germans to converge. Note, however, that, in addition to the difference in outcome variables between the two papers, the source of divergence in our present paper is a variation within East Germany, and not between East and West.
} 
examining the impact of exposure to West German TV on aggregate consumption behavior after reunification, using the EVS data. For that purpose, we use the following regression setup:

$$
y_{i}=\beta_{0}+\beta_{1} \text { Treatment }_{i}+x_{i}^{\prime} \gamma+\varepsilon_{i}
$$

where $y_{i}$ are variables relating to the aggregate consumption behavior of household $i$, Treatment $t_{i}$ is a treatment indicator equal to one for households with access to Western TV, and $x_{i}$ is a set of household-level covariates, including economic and demographic characteristics (see Table 4 for a list of covariates used in our regressions). The coefficient of interest is $\beta_{1}$. Our main outcome variables of interest are the log of disposable income, the log of total private consumption, and a dummy on whether the household has positive levels of savings. We run separate regressions for 1993 and $1998 .^{27}$

If households in the treatment area (those previously exposed to Western television) wanted to consume relatively more than those in the control area, we would observe them either supplying relatively more labor (thus increasing their incomes compared to households in the control area), saving relatively less, or resorting relatively more to credit to finance their consumption.

Table 5 shows the treatment effects of long-term exposure to Western television on disposable income, total private consumption, and savings. The results indicate that East German households with Western TV access before 1990 do not differ from the control group in their aggregate behavior: the treatment effects on disposable income, total private consumption, and savings are all statistically insignificant, both in 1993 and 1998. Moreover, all estimates can rule out even modest increases in total private consumption associated with exposure to Western TV: based on the 1993 estimates (Panel A, column 2), we can rule out with 95\% confidence an increase of less than $1.5 \%$ in total private consumption.

[Table 5 about here]

In Table 6, we look at the treatment effects on the use of financial instruments. We analyze the effect of previous exposure to Western television on the likelihood of reporting to have taken

\footnotetext{
${ }^{27}$ Note that since the EVS is conducted as a repeated cross-section (rather than a panel) we are not able to link households across waves.
} 
consumer credit and to have overdraft payments on a checking account, using a linear probability model. If households in the treatment area felt a comparatively stronger need to buy the consumption goods seen on Western television after they suddenly became available in 1990, they could have resorted to consumer credit or overdraft on bank accounts to finance those purchases. Repayment of these credits would then still be visible in 1993. However, the absence of significant treatment effects in the regressions of Table 6 does not corroborate this hypothesis. Here, too, the estimates are precise enough to rule out meaningful quantities: in 1993, we can rule out with 95\% confidence a propensity to resort to consumer credit that is $6 \%$ higher in the treated regions, and a propensity to resort to overdraft that is $1 \%$ higher.

\section{[Table 6 about here]}

The general picture is therefore one of lack of effects on aggregate consumption behavior. Unfortunately, we cannot address whether this is due to previous exposure to West German television truly not affecting post-reunification aggregate consumption, the effects having already vanished in 1993, or households being constrained in their ability to adjust aggregate consumption behavior. Yet, the absence of effects on aggregate variables does not preclude an alternative kind of effect: long-term exposure to West German television could have affected the composition of consumption after reunification, shifting consumption towards some particular categories of goods.

\subsection{West German TV advertising and the composition of consumption}

We expect advertising to be an important channel through which Western television might impact consumption choices. To study how advertising, present in West German television but not in East German broadcasts, affected post-reunification composition of consumption, we use data about the quantity of advertising (measured in minutes) on West German TV stations between 1980 and 1989 (Zentralausschuss der Werbewirtschaft, ed., 1980-1989). Table 7 lists categories of goods ranked by the percentage of total minutes of advertising on the main West German TV channel, ARD. Food and drinks as well as body care products make up the largest part of advertising on television, whereas other categories of goods, such as clothing or tourism, make up for a much 
smaller share of total advertising time..$^{28}$

[Table 7 about here]

The effects of advertising on consumption patterns could conceivably take different forms. Exposed households could consume more of the more heavily advertised brands of a given product, preferring them to "no-name" items. This would correspond to having a higher brand-recognition factor for advertised goods among East German citizens who had watched Western television previously. With the data available to us, we are not able to test this hypothesis; both the advertising figures in Table 7 and the categories of consumption goods in the EVS are not detailed up to the level of brands. Here, rather than focusing on shifts across brands, we examine whether households spend more on categories of goods that, according to the figures of Table 7, were more heavily advertised on television to the detriment of those categories of consumption goods that were less advertised. ${ }^{29}$ We matched the items recorded in the EVS surveys to the categories of Table 7. Other types of consumption goods present in the exhaustive catalog of the EVS are not present at all among the goods advertised on television: e.g., expenditures for house rental, utilities, bicycles, or telephones. For those goods, we created an eleventh category corresponding to all goods with zero share of advertising time.

To first visualize the effects of Western television advertising on consumption choices, we examine Figures 5 and 6, which display the logarithm of raw differences between treatment and control regions in average yearly consumption levels by categories of consumption. The categories of consumption goods are sorted along the horizontal axis according to their shares of total advertising time averaged over the period 1980-1989, as in Table 7. Each figure also plots a linear fit of the raw data, weighting categories of consumption by their budget share. We choose to weight regressions according to the budget shares of the goods categories in order not to give

\footnotetext{
${ }^{28}$ Note that the overall amount of advertising on the state television broadcasting stations was low, totaling less than 20 minutes per day on average. These amounts, as well as the times of the day in which advertising was allowed, were regulated by law (Rundfunkstaatsvertrag of 1987, §3). Most of the advertising occurred in the "prime time" between 7 and $8 \mathrm{pm}$.

${ }^{29}$ The question whether advertising is, within categories of goods, "predatory" (i.e., one brand advertises at the detriment of the other brands) or "cooperative" (advertising increases overall sales) has been discussed in the industrial organization literature. See, for example, Rojas and Peterson (2008) for the beer industry. In the context of our study, we would find any effects only if advertising was cooperative within goods categories.
} 
undue weight to categories that are considered separately in the (arguably arbitrary) classification of the German advertising statistics, but have little importance in most households' budgets: e.g., the category "Photo, optics, watches, jewelry," which makes up for only $1.1 \%$ of the budget of the average household in 1993 (see Table 7, third column).

[Figure 5 about here]

[Figure 6 about here]

The figures suggest that in 1993 (Figure 5), higher intensity of advertising was associated with (significantly) larger consumption in the treatment areas compared to the control areas. The slope of the line is 0.0024 with an associated $t$-statistic of 2.20. On average, most categories of consumption goods display a negative difference between treatment and control area; this is consistent with the negative (but not significant) effect of treatment status on total private consumption (Table 5, Panel A, column 2). In 1998 (Figure 6), the effects seem to have vanished, with a slope of 0.0003 (and a $t$-statistic of 0.25 ).

We now proceed with our regression analysis of the effects of Western TV advertising on consumption choices. Our basic regression setup can be described as follows:

$$
\begin{aligned}
\ln \left(1+\text { Expenditures }_{i j}\right)= & \beta_{0}+\beta_{1} \text { Advertising }_{j}+\beta_{2} \text { Treatment }_{i} \\
& \left.+\beta_{3} \text { (Treatment }_{i} \times \text { Advertising }_{j}\right)+\varepsilon_{i j},
\end{aligned}
$$

where Expenditures ${ }_{i j}$ are expenditures of household $i$ on good $j$, Treatment ${ }_{i}$ is a treatment indicator equal to one for households with access to Western TV, and Advertising $g_{j}$ is the average number of minutes of TV advertising per day devoted to good category $j$ in the 1980-1989 period (as in Table 7). We add 1 to Expenditures ${ }_{i j}$ when taking logs to avoid dropping observations with zero consumption. The coefficient of interest is $\beta_{3}$ and relates to the interaction term Treatment $_{i} \times$ Advertising $_{j}$. If individuals exposed to Western television spend more on the more heavily advertised goods, then $\beta_{3}>0$. We first cluster standard errors at the municipality level. 
In our baseline specification, regressions are weighted both by the EVS sampling weights and by the budget share of each category of consumption goods.

Alternatively, we can add a set of household-level covariates $x_{i}$ (as in the previous section of the paper):

$$
\begin{aligned}
\ln \left(1+\text { Expenditures }_{i j}\right)= & \beta_{0}+\beta_{1} \text { Advertising }_{j}+\beta_{2} \text { Treatment }_{i} \\
& \left.+\beta_{3} \text { (Treatment }_{i} \times \text { Advertising }_{j}\right)+x_{i}^{\prime} \gamma+\varepsilon_{i j}
\end{aligned}
$$

The inclusion of household-level covariates does not affect the point estimates $\beta_{1}$ or $\beta_{3}$ since Advertising $_{j}$ does not vary at the household level, and the effect of Treatment ${ }_{i}$ at the household level is captured by $\beta_{2}$. Conditional on Advertising And Treatment $_{i}$, the interaction term of these variables is orthogonal to covariates $x_{i}$ that vary only at the household level.

Table 8 presents the results of estimating our regression model (2), once for the 1993 EVS survey (Panel A) and once with the 1998 data (Panel B). In column 1, we present the results following the setup in equation 2, and in column 2 we show the results associated with the baseline specification adding household-level covariates, as in equation 3. The coefficient on intensity of advertisement, $\beta_{1}$ shows that, in the control region, categories of goods with more advertising are associated with higher expenditures. ${ }^{30}$ The direct effect of a household's location in the treatment area, $\beta_{2}$, is negative but not significant; note that this corresponds to the direct effect in the case of a category of goods with zero advertising. As one moves to goods categories with a higher intensity of advertising, households in the treatment group consume more than those in the control region. This can be derived from the fact that the coefficient on the interaction term Treatment $_{i} \times$ Advertising $_{j}$, $\beta_{3}$, is positive and significant at the $1 \%$ level. Note that, as predicted, the inclusion of household covariates in column 2 only affects the point estimate of $\beta_{2} .^{31}$

\section{[Table 8 about here]}

\footnotetext{
${ }^{30}$ This is expected, since some categories with high intensity of advertising (e.g., food) are large items in household budgets. The coefficient $\beta_{1}$ cannot be interpreted as a (causal) effect of advertising on consumption.

${ }^{31}$ Analogously, including a full set of interaction terms between the treatment dummy and household covariates would not affect the point estimate of the interaction term, $\beta_{3}$.
} 
In column 3, we use the share of total advertising time, rather than minutes of advertising per day, as the explanatory variable: the coefficient of interest now measures the differential effect in treatment versus control areas of one more percentage point of total advertisement time during the 1980s, rather than one more minute per day, on the logarithm of expenditures. The estimates of the coefficients $\beta_{1}$ and $\beta_{3}$ are rescaled accordingly, but do not change their qualitative interpretation. Column 4 does not weight the regression observations by the budget shares of the respective consumption goods categories (it uses only the original sampling weights from the EVS survey). Again, this does not affect the main findings. The magnitude of the coefficient $\beta_{3}$ is increased, although the coefficient is less precisely estimated (it is now significant at the $5 \%$ level). ${ }^{32}$

Finally, in column 5, we reproduce the baseline regression using the continuous treatment variable instead of the binary treatment indicator. The point estimate for $\beta_{3}$ is slightly larger than in the previous specifications, and still highly significant. ${ }^{33}$

The economic magnitude of the coefficients is not minor. The estimated coefficient using our baseline specification (column 1) indicates that spending on a category of goods that had on average one more minute of advertising per day between 1980 and 1989 was about 1.5\% larger in the treatment area, when compared to the control area. If we look instead at column 3, which uses the share of total advertising time as the main explanatory variable, we observe that a one percentage point increase in the share of total advertisement allocated to a category of goods is associated with about $0.25 \%$ more consumption in the treatment area when contrasted with areas not exposed to the advertisements. To have a better sense of the size of these effects, note that the estimated coefficient in column 3, 0.246, implies that consumer expenditures for body care products, a rather heavily advertised class of products (with $17.9 \%$ of total advertising time), were approximately $4.4 \%(=17.9 \times 0.246)$ higher in areas with access to Western TV.

At the same time, the results reported in Panel B show that the effects have all but disappeared by 1998. The estimated coefficient for Treatment ${ }_{i} \times$ Advertising $_{j}$ is now insignificant and, perhaps

\footnotetext{
${ }^{32}$ It is interesting to note that, as expected due to the lack of increases in total consumption among households previously exposed to West German TV, the coefficient $\beta_{2}$-the effect of the treatment on consumption categories with zero share of advertisement time-is always negative (e.g., in column 1, it corresponds to a consumption level in those categories almost 9\% lower in the treatment areas).

${ }^{33}$ In Appendix Tables A.8 and A.9 we reproduce all other results from this Table, and from the other analyses based on the EVS, using the continuous treatment variable instead of the binary treatment indicator. All results are confirmed and comparable in both magnitude and significance.
} 
more importantly, clearly smaller in magnitude across all specifications. For example, in our baseline specification of column 1 , the effect declines to about one seventh of the size measured for 1993.

Another way to appreciate the magnitudes of the estimated effects is to gauge how large the likely effect was just after reunification; recall that the results of Panel A stem from the survey conducted in 1993, three years after the East was integrated into the West German economy and all households in the former GDR were exposed to the same TV stations and had access to the same types of goods. As a back-of-the envelope calculation, assume that the treatment effect of exposure to Western television and its advertising content declines linearly over time. In that case, the decline witnessed between 1993 and 1998 for the specification of column (1) corresponds to a hypothetical effect of 2.341 in 1990, the year of German reunification: that is, an effect of approximately $2.3 \%$ more consumption expenditures for every additional minute of television advertising time on average between 1980 and 1989 spent on a given category of goods. ${ }^{34}$

It is important to note that our results are robust to dropping single categories of consumption goods one at a time, as displayed in Appendix Table A.7. The only case in which our coefficient of interest $\left(\beta_{3}\right)$ is no longer significant in 1993 is when we drop the Food, drinks category. The point estimate for $\beta_{3}$ is actually $25 \%$ larger when we drop that category (compared to our baseline specification), indicating that the category is not an outlier. We lose precision when dropping that category since it is the most important category in in terms of its budget share in 1993 (accounting for $23.7 \%$ of the budget). Since we weigh regressions by the budget share of each category, dropping the Food, drinks category implies a large reduction in our effective sample size, thus reducing the precision of our estimates.

As a whole, the regression results draw a picture in which East German households in the treatment areas (i.e., with access to Western television until 1990) are particularly susceptible to pre-reunification advertising when making the choice between different categories of consumption goods in the early post-reunification period.

\footnotetext{
${ }^{34}$ The persistence of the effect of advertising of the 1980s into the 1990s is even more remarkable if one considers that the marketing literature (Lodish et al., 1995) finds that the carryover effect of advertising is about 6 to 9 months, and is even weaker in absence of reinforcement through actual purchases (Givon and Horsky, 1990).
} 


\subsection{Robustness checks: Changing samples, clustering, treatment definition}

Table 9 presents further robustness checks, departing from the baseline regression of Table 8, column 1 (budget shares weights, binary treatment indicator, no household covariates). In column 1, we reproduce the regressions clustering at the household level, rather than at the municipality level, as in Table 8. All standard errors are now smaller than before, suggesting that clustering at the municipality level, by taking into account the correlation across households in the same municipality, is the more conservative approach. ${ }^{35}$

In column 2, we include observations from East Berlin, which were originally dropped in Table 8. Again, all findings are virtually unchanged. In columns $3-5$, we vary our definition of threshold for availability of West German TV broadcasts (by $2 \mathrm{~dB}$ each time to $-84.8 \mathrm{~dB},-82.8 \mathrm{~dB}$, and $-80.8 \mathrm{~dB}$ ) to see if our findings are robust to variations on the level of signal strength that defines treatment and control. ${ }^{36}$ The coefficients of interest in columns 3-5 are similar to the baseline coefficients from column 1 in Table 8 and are also significant at the $1 \%$ level.

Just as before, the effects are much smaller and no longer significant in 1998, as observed in Panel B of Table 9.

[Table 9 about here]

In Table 10, we proceed with a different set of robustness checks. Instead of varying the definition of our threshold of signal availability, as in Table 9, we now restrict our areas of analysis to regions with West German TV signal strength sufficiently close to our original threshold of signal availability. This approach is in the spirit of a regression-discontinuity design, although we do not have a clear discontinuity in signal availability. We restrict the analysis to regions in which the signal strength is within $30 \mathrm{~dB}$ (column 1), $20 \mathrm{~dB}$ (column 2), or $10 \mathrm{~dB}$ (column 3 ) of the original $-86.8 \mathrm{~dB}$ threshold.. ${ }^{37}$ In the first two settings, our results hold and are quantitatively very similar to the baseline results from Table 8 In Table 10, Panel B, we observe that the results have either decreased or disappeared by 1998.

\footnotetext{
${ }^{35}$ In Appendix Table A.6, we show that our results are robust to aggregating households into larger clusters.

${ }^{36}$ We do not change the threshold in the other direction, since that would assign the entire municipality of Dresdenwhich was known to have virtually no access to Western television broadcasts- to the treatment area.

${ }^{37}$ See the Supplemental Appendix, Tables A.10-A.12, for a comparison of household covariates in the treatment and control areas under the three different sample restrictions criteria of Table 10.
} 
If we further restrict our sample to regions in which the signal strength is within $10 \mathrm{~dB}$ of the original threshold, our results no longer hold, as observed in column 3 of Table 10. This is not surprising in the light of the survey evidence presented in Figure 2, which suggests that the discontinuity threshold lay approximately between -75 and $-86 \mathrm{~dB}$. Since the discontinuity in access to West German TV signals is not sharp, many individuals in the "treatment" area within $10 \mathrm{~dB}$ of the original threshold would most likely not have access to the broadcasts on a everyday basis, either. In practice, in the sample restricted to $-86.8 \pm 10 \mathrm{~dB}$ one would be comparing individuals with no exposure to West German TV with individuals with very little exposure to West German $\mathrm{TV}$, thus attenuating our findings.

\section{[Table 10 about here]}

\subsection{The effect of distance to West Germany}

An alternative explanation for the findings of the previous subsection could be that such results are simply the product of the control areas' distance from the West German border. Such longer distance could make the access to Western goods more difficult, increase the time that Western goods take to penetrate the local market, among other plausible factors that could affect consumption choices. Although we have no reason to think that the goods that were less likely to penetrate the local market in the control areas were also the ones with higher intensity of advertising, it is important to address that alternative explanation. To examine that, in Table 11, we reproduce our main analysis adding as a covariate the minimum driving distance (in kilometers) between any household's municipality of residence in our data set and the closest point in former West Germany (including the exclave of West Berlin). To compute this variable, we used the actual East German road and highways network as of 1990.

Having the explanatory variable "availability of West German TV broadcasts" compete with the shortest distance to either the West German border or West Berlin makes for a strong test of our hypotheses: the effects will thus only be identified from those cases where geographic features of the landscape do not reduce travel distance but prevent TV signals to reach the households in the survey. The empirical setup chosen corresponds to equation (2); however, in addition to 
the interaction of interest Treatment T $_{i} \times$ Advertising $_{j}$, we include a further variable representing the interaction between the intensity of advertising and distance to West Germany: Distance ${ }_{i} \times$ Advertising. ${ }_{j} .3$

\section{[Table 11 about here]}

The results in column 1 show that the main coefficient of interest is entirely unaffected by the inclusion of the distance measure. This makes us confident that the estimated effects stem, in fact, from differential access to West German broadcasts before 1990, and not merely from distance to West German markets.

An alternative way to assess the potentially confounding effect of distance is to run placebo regressions restricting our sample to the treatment region only, where Western TV signal was available before 1990. If distance, and not access to Western TV, explained the difference of consumption patterns, this effect should be visible also when considering the variation within the treatment region only, i.e. among those households that had access to Western TV throughout. Here we use interaction of distance to West Germany with advertising time as the explanatory variable of interest. As shown in column 2 of Table 11, distance to West Germany does not explain the differences in consumption choices within the region with access to Western broadcasts.

\section{Conclusion}

We study the impact of long-term exposure to Western television on consumption behavior exploiting a setting with plausibly exogenous variation of the explanatory variable: differential access to Western television in former East Germany, a variation that was mainly determined by geographic features.

While our data do not support the hypothesis that Western television shifts aggregate consumption patterns (total private consumption, savings), we provide evidence consistent with Western television affecting the composition of consumption through advertising. Expenditures

\footnotetext{
${ }^{38}$ We also reproduce tables 5 and 6 (i.e., the regressions relating to aggregate consumption behavior from section 4.2) adding our distance to West Germany variable, and the coefficient of interest (on the treatment indicator) always continues to be insignificant. Results are available from the authors upon request.
} 
on categories of goods with higher shares of advertising time on pre-reunification Western television were, after 1990, higher in the areas reached by Western broadcasts. Our unique setting allows for a well-identified analysis of the causal impact of long-term exposure to advertising on consumption behavior, since the East Germans that could watch West German broadcasts were not the targeted audience of the advertising.

Our findings also suggest that television advertising changes consumption patterns in a way that is more than just to induce individuals to switch across brands of the same good. Advertising may induce a recomposition of consumption across broad categories of goods, depending on the amount of advertising for each category. 


\section{References}

Alesina, Alberto and Nicola Fuchs-Schündeln, "Good Bye Lenin (or Not?): The Effect of Communism on People's Preferences," American Economic Review, 2007, 97 (4), 1507-1528.

Avery, Rosemary, Donald Kenkel, Dean Lillard, and Alan Mathios, "Private Profits and Public Health: Does DTC Advertising of Smoking Cessation Products Encourage Smokers to Quit?," Journal of Political Economy, 2007, 115 (3), 447-481.

Bagwell, Kyle, "The Economic Analysis of Advertising," in Mark Armstrong and Rob Porter, eds., Handbook of Industrial Organization, Vol. 3, Amsterdam: North-Holland, 2007, pp. 1701-1844.

Baker, Matthew J. and Lisa M. George, "The Role of Television in Household Debt: Evidence from the 1950's," The BE Journal of Economic Analysis E Policy, 2010, 10 (1), 1-36.

Becker, Gary S. and Kevin M. Murphy, "A Simple Theory of Advertising as a Good or Bad," Quarterly Journal of Economics, November 1993, 108 (4), 941-964.

Benhabib, Jess and Alberto Bisin, "Advertising, Mass Consumption and Capitalism," February 2002. Unpublished manuscript, NYU.

Beutelschmidt, Thomas, Sozialistische Audiovision, Vol. 3 of Veröffentlichungen des Deutschen Rundfunkarchivs, Potsdam: Verlag für Berlin-Brandenburg, 1995.

Bronnenberg, Bart, Jean-Pierre Dube, and Matthew Gentzkow, “The Evolution of Brand Preferences: Evidence from Consumer Migration," February 2011. Unpublished manuscript, University of Chicago.

Buhl, Dieter, "Window to the West: How Television from the Federal Republic Influenced Events in East Germany," 1990. Discussion paper D-5, Joan Shorenstein Barone Center, Harvard University.

Burchardi, Konrad B. and Tarek A. Hassan, "The Economic Impact of Social Ties: Evidence from German Reunification," NBER Working Paper, June 2011, 17186.

Cameron, A. Colin, Jonah B. Gelbach, and Douglas L. Miller, "Bootstrap-based Improvements for Inference with Clustered Errors," Review of Economics and Statistics, August 2008, 90 (3), 414427.

Chang, Chun-Fang and Brian Knight, "Media Bias and Influence: Evidence from Newspaper Endorsements," 2011. Forthcoming, Review of Economic Studies.

Claus, Werner, ed., Medien-Wende, Wende-Medien? Dokumentation des Wandels im DDR- Journalismus, Berlin: Vistas, 1991.

DellaVigna, Stefano and Ethan Kaplan, “The Fox News Effect: Media Bias and Voting," Quarterly Journal of Economics, August 2007, 122 (3), 1187-1234.

- and Matthew Gentzkow, "Persuasion: Empirical Evidence," Annual Review of Economics, 2010, 2, 643-669. 
_, Ruben Enikopolov, Vera Mironova, Maria Petrova, and Ekaterina Zhuravskaya, "Unintended Media Effects in a Conflict Environment: Serbian Radio and Croatian Nationalism," NBER Working Paper, May 2011, 16989.

Dixit, Avinash K. and Victor Norman, "Advertising and Welfare," Bell Journal of Economics, Spring 1978, 9 (1), 1-17.

Economist, "North Korea: Rumblings from below," 2013. Feb 9.

Enikolopov, Ruben, Maria Petrova, and Ekaterina Zhuravskaya, "Media and Political Persuasion: Evidence from Russia," American Economic Review, 2011, 111 (7), 3253-3285.

Frank, Rüdiger, "Money in Socialist Economies: The Case of North Korea," The Asia-Pacific Journal, February 22, 2010, 8-2-10.

_ , "North Korea in 2011: Domestic Developments and the Economy," in Rüdiger Frank, James E. Hoare, Patrick Köllner, and Susan Pares, eds., Korea 2012: Politics, Economy and Society, Leiden: Brill, 2012, pp. 39-64.

Friedrich, Walter, Peter Förster, and Kurt Starke, eds, Das Zentralinstitut für Jugendforschung Leipzig 1966-1990, Berlin: Edition Ost, 1999.

Friehe, Tim and Mario Mechtel, "Conspicuous Consumption and Communism: Evidence from East and West Germany," CESifo Working Paper Series, 2012, 3922.

Galbraith, John Kenneth, The Affluent Society, Boston: Houghton Mifflin, 1958.

Gentzkow, Matthew, “Television and Voter Turnout," Quarterly Journal of Economics, 2006, 121, 931-972.

- and Jesse Shapiro, "Media, Education and Anti Americanism in the Muslim World," Journal of Economic Perspectives, 2004, 18 (3), 117-133.

Gerber, Alan S., Dean Karlan, and Daniel Bergan, "Does the Media Matter? A Field Experiment Measuring the Effect of Newspapers on Voting Behavior and Political Opinions," American Economic Journal: Applied Economics, 2009, 1 (2), 35-52.

Givon, Moshe and Dan Horsky, "Untangling the effects of purchase reinforcement and advertising carryover," Marketing Science, 1990, 9 (2), 171-187.

Grundmann, Siegfried, Bev"olkerungsentwicklung in Ostdeutschland, Opladen: Leske+Budrich, 1998.

Grünert, Holle, "Das Beschäftigungssystem der DDR," in Burkart Lutz, Hildegard M. Nickel, Rudi Schmidt, and Arndt Sorge, eds., Arbeit, Arbeitsmarkt und Betriebe, Opladen: Leske+Budrich, 1996.

Hesse, Kurt R., Westmedien in der DDR, Köln: Verlag Wissenschaft und Politik, 1988.

Hu, Ye, Leonard M. Lodish, and Abba M. Krieger, "An analysis of real world TV advertising tests: A 15-year update," Journal of Advertising Research, 2007, 47 (3), 341. 
Hufford, George A., "The ITS Irregular Terrain Model, version 1.2.2.: The Algorith," 1995. mimeo, National Telecommunications and Information Administration, Institute for Telecommunication Sciences, Boulder, Colo.

Hunt, Jennifer, "Staunching Emigration from East Germany: Age and the Determinants of Migration," Journal of the European Economic Association, 2006, 4 (5), 1014-1037.

Jensen, Robert and Emily Oster, "The Power of TV: Cable Television and Women's Status in India," Quarterly Journal of Economics, 2009, 143 (3), 1057-1094.

Kaminsky, Annette, Wohlstand, Schönheit, Glück: Kleine Konsumgeschichte der DDR, München: C.H. Beck, 2001.

Kern, Holger Lutz and Jens Hainmueller, "Opium for the Masses: How Foreign Media Can Opium for the Masses: How Foreign Media Can Stabilize Authoritarian Regimes," Political Analysis, 2009, 17, 377-399.

La Ferrara, Eliana, Alberto Chong, and Suzanne Duryea, "Soap Operas and Fertility: Evidence from Brazil," American Economic Journal: Applied Economics, 2012, forthcoming.

Lankov, Andrei, "Low-Profile Capitalism: The Emergence of the New Merchant/Entrepreneurial Class in Post-Famine North Korea," in Kyung-Ae Park and Scott Snyder, eds., North Korea in Transition, Lanham, Md.: Rowman \& Littlefield, 2013, chapter 8, pp. 197-194.

Lodish, Leonard M., Moshe M. Abraham, Jeanne Livelsberger, Beth Lubetkin, B. Richardson, and Mary Ellen Stevens, "A summary of fifty-five in-market experimental estimates of the long-term effect of TV advertising," Marketing Science, 1995, 14 (3 supplement), G133-G140.

Marshall, Monty G., Keith Jaggers, and Ted Robert Gurr, "Polity IV Project: Political Regime Characteristics and Transitions, 1800-2010," 2010. Center for Systemic Peace.

Milgrom, Paul and John Roberts, "Price and Advertising Signals of Product Quality," Journal of Political Economy, 1986, 94 (4), 796-821.

Müller, Susanne, Von der Mangel-zur Marktwirtschaft, Leipzig: mimeo, IM Leipzig, 2000.

Nelson, Phillip, “Advertising as Information," Journal of Political Economy, 1974, 82 (4), 729-754.

Norddeutscher Rundfunk, ed., Hörfunk und Fernsehsender in der Bundesrepublik Deutschland einschließlich Berlin (West) nach dem Stand vom 1. Januar 1989, Wedel (Holstein): Norddeutscher Rundfunk, 1989.

Olken, Benjamin A., "Do TV and Radio Destroy Social Capital? Evidence from Indonesian Villages," American Economic Journal: Applied Economics, 2009, 1 (4), 1-33.

Pušnik, Maruša and Gregor Starc, "An entertaining (r)evolution: the rise of television in socialist Slovenia," Media, Culture E Society, 2008, 30 (6), 777-793.

Putman, Robert D., Bowling alone: the collapse and revival of American community, New York: Simon \& Schuster, 2000. 
Rojas, Christian and Everett B. Peterson, "Demand for differentiated products: Price and advertising evidence from the US beer market," International Journal of Industrial Organization, 2008, $26(1), 288-307$.

Schneider, Gernot, "Lebensstandard und Versorgungslage," in Eberhart Kuhrt, Hannsjörg F. Buck, and Gunter Holzweißig, eds., Die wirtschaftliche und ökologische Situation der DDR in den 80er Jahren, Vol. 2 of Am Ende des realen Sozialismus, Opladen: Leske+Budrich, 1996, pp. 111-136.

Schor, Juliet B., The Overspent American: Upscaling, Downshifting, and the New Consumer, New York: Basic Books, 1998.

Sethuraman, Raj, Gerard J. Tellis, and Richard A. Briesch, "How well does advertising work? generalizations from meta-analysis of brand advertising elasticities," Journal of Marketing Research, 2011, 48 (3), 457-471.

Sinn, Gerlinde and Hans-Werner Sinn, Jumpstart: The Economic Unification of Germany, Cambridge, Mass.: MIT Press, 1992.

Smith, Adam, An Inquiry into the Nature and Causes of the Wealth of Nations, New York: Modern Library, 1776/2000.

Snyder, Jim and David Strömberg, "Press Coverage and Political Accountability," Journal of Political Economy, 2008, 118 (2), 355-408.

Statistisches Amt der DDR, ed., Statistisches Jahrbuch der Deutschen Demokratischen Republik, Berlin: VEB Deutscher Zentralverlag, (various years).

Stiehler, Hans-Jürgen, Leben ohne Westfernsehen, Leipzig: Leipziger Universitätsverlag, 2001.

Strömberg, David, "Radio's Impact on Public Spending," Quarterly Journal of Economics, 2004, 119 (1), 189-221.

Wind, Yoram and Byron Sharp, "Advertising Empirical Generalizations: Implications for Research and Action," Journal of Advertising Research, 2009, 49 (2), 246.

Yanagizawa-Drott, David, "Propaganda and Conflict: Theory and Evidence From the Rwandan Genocide," 2010. Unpublished, Harvard Kennedy School.

Zentralausschuss der Werbewirtschaft, ed., Werbung in Deutschland, Bonn: Zentralausschuss der Werbewirtschaft, (various years). 
Figures and Tables

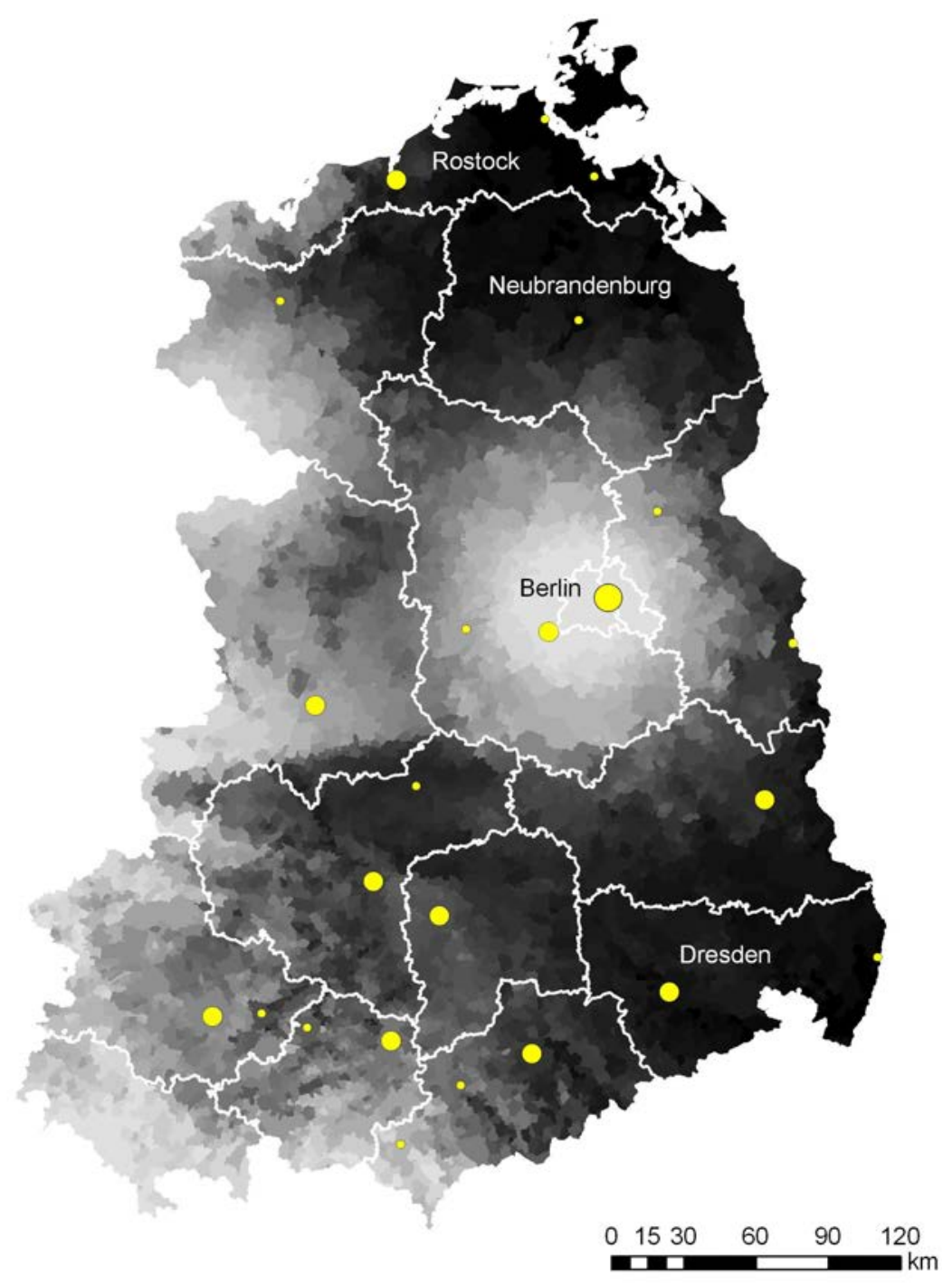

Figure 1: Signal strength (ARD) in East Germany, 1989. Dark: weak signal. (Yellow) dots represent major cities. District borders (Bezirke) superimposed as white lines. 

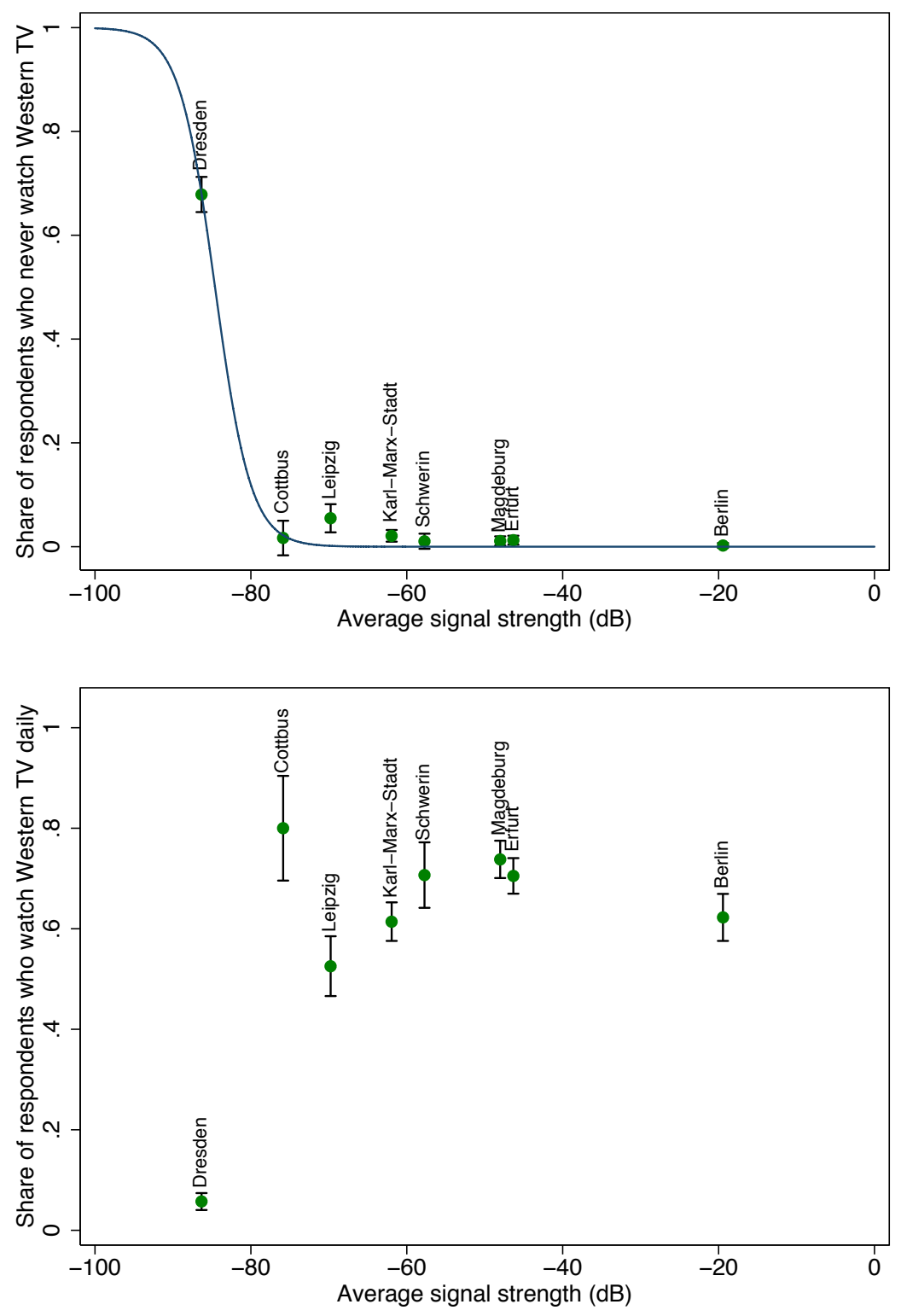

Figure 2: Average viewership of Western TV channels, by district (Bezirk). Share responding "daily" (upper panel) and "never" (lower panel). Omitted categories: "several times per week," "once per week," "less than once per week." Bars indicate 95\% confidence intervals. Some districts were not covered in this survey. The upper panel also displays the best fit of a logistic cdf to the observed data. Source: Zentralarchiv für Empirische Sozialforschung ZA 6008. 


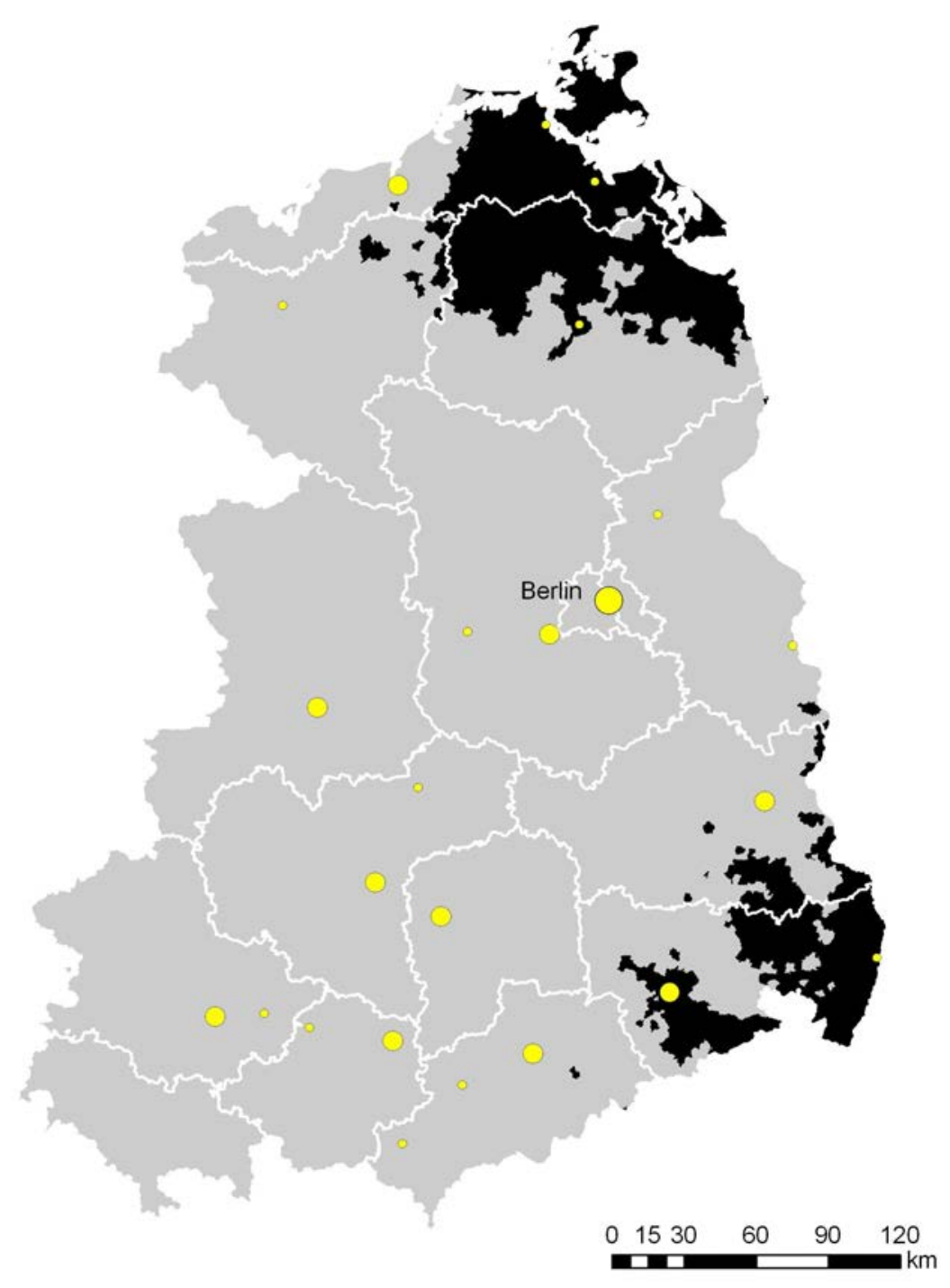

Figure 3: Signal strength (ARD) in East Germany, 1989. Dark: Signal strength below -86.7dB (threshold based on signal availability in Dresden). (Yellow) dots represent major cities. District borders (Bezirke) superimposed as white lines. 


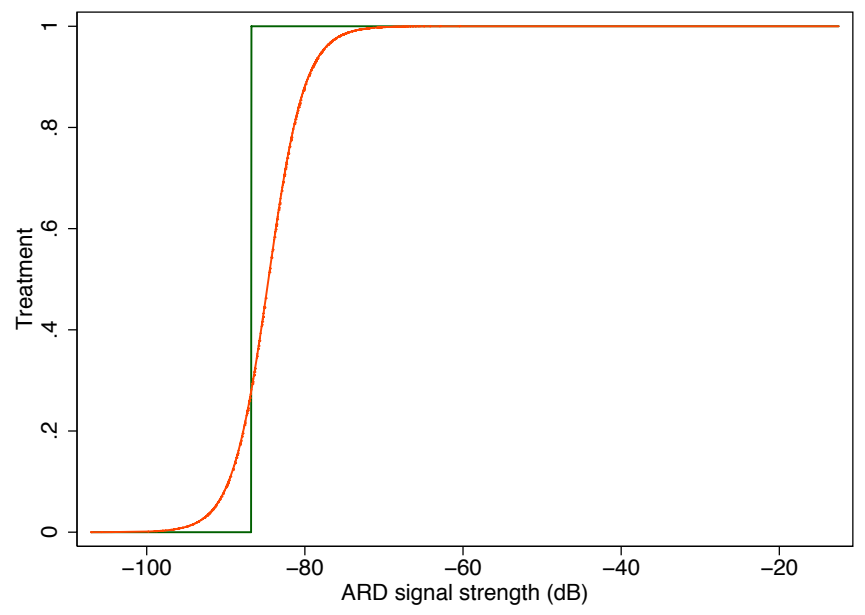

Figure 4: Treatment definitions. The figure compares the binary treatment definition, based on the threshold of $-86.7 \mathrm{~dB}$, and the continuous treatment definition, based on the fit of actual viewership data as in Figure 2, upper panel. 


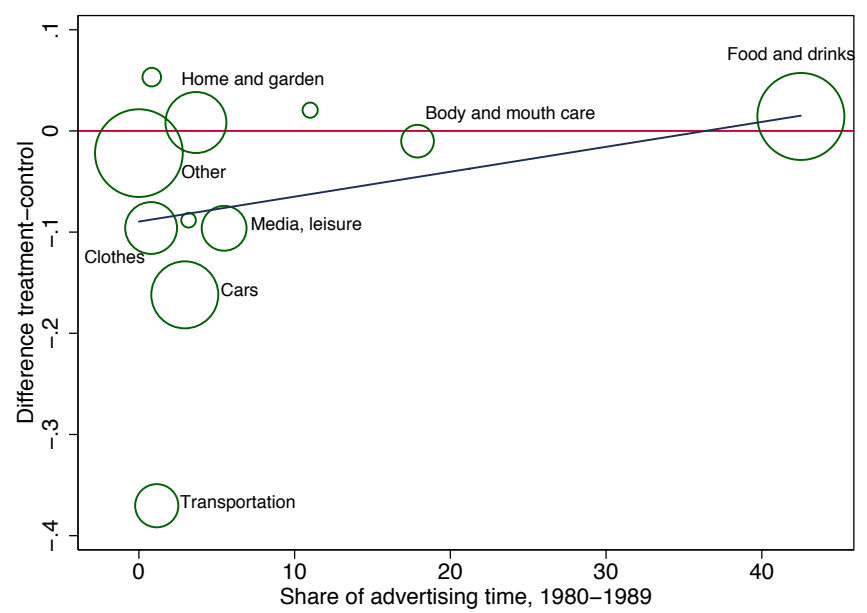

Figure 5: Differences in consumption levels and advertising (1993). The horizontal axis reports shares of total advertising time, 1980-1989, as in Table 7. The vertical axis reports (the logarithm of) raw differences between treatment and control regions in average yearly consumption levels. Circle sizes proportional to the budget share of each category of consumption good. Major categories are labeled. Appendix Table A.5 presents the raw data underlying this figure.

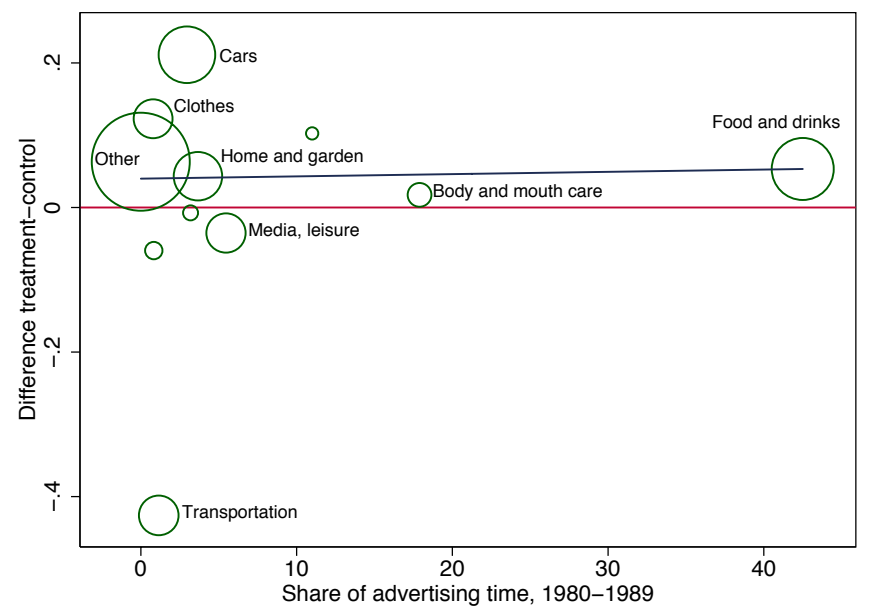

Figure 6: Differences in consumption levels and advertising (1998). (Interpretation: see above) 
Table 1: Regional characteristics 1955 and 1990 (district level), by treatment status

\begin{tabular}{|c|c|c|c|c|c|}
\hline & Treatment & Control & Diff. & Std. err. & $\mathrm{p}$-value \\
\hline \multicolumn{6}{|l|}{ Panel A: 1955 (district level data) } \\
\hline Population density (inhab. $/ \mathrm{km}^{2}$ ) & 206 & 202 & 4 & 77 & 0.959 \\
\hline Share of employed in agriculture (\%) & 23.7 & 27.8 & -4.1 & 11.1 & 0.744 \\
\hline Share of employed in industry (\%) & 34.1 & 28.7 & 5.4 & 10.0 & 0.635 \\
\hline Retail sales per capita (Mark) & 1691 & 1694 & -3 & 102 & 0.979 \\
\hline Savings per capita (Mark) & 277 & 297 & -20 & 28 & 0.544 \\
\hline \multicolumn{6}{|l|}{ Panel B: 1990} \\
\hline Population density (inhab. $/ \mathrm{km}^{2}$ ) & 181 & 176 & 5 & 62 & 0.941 \\
\hline Share empl. in agriculture (\%) & 13.5 & 11.3 & 2.2 & 5.1 & 0.706 \\
\hline Share empl. in industry (\%) & 33.2 & 39.5 & -6.3 & 7.5 & 0.479 \\
\hline Retail sales p.c. (Mark) & 7577 & 7250 & 327 & 188 & 0.190 \\
\hline Savings p.c. (Mark) & 9312 & 9381 & -69 & 928 & 0.946 \\
\hline Cars per 1000 inhab. & 237.4 & 237.6 & -0.2 & 12.1 & 0.992 \\
\hline \multicolumn{6}{|l|}{ Panel C: Difference 1990-1955 } \\
\hline Population density (inhab. $/ \mathrm{km}^{2}$ ) & -18 & -26.2 & 8.2 & 15.4 & 0.626 \\
\hline Share empl. in agriculture (\%) & -14.5 & -12.6 & -1.9 & 6.0 & 0.778 \\
\hline Share empl. in industry (\%) & 5 & 5.5 & -0.5 & 3.0 & 0.870 \\
\hline Retail sales p.c. (Mark) & 5862 & 5557 & 305 & 157 & 0.142 \\
\hline Savings p.c. (Mark) & 8946 & 8994 & -48 & 770 & 0.954 \\
\hline
\end{tabular}

Population-weighted averages, excluding the district of East Berlin. P-values based on weighted Welch's t-tests of difference in means (two-sided, allowing for unequal variances). Total number of districts: 14 (11 treatment, 3 control). Source: Statistisches Amt, ed, Statistisches Jahrbuch der DDR, 1955 and 1990.

Table 2: Migration rates 1991-1993 (county level), by treatment status

\begin{tabular}{lrrrrr}
\hline Variable & Treatment & Control & Diff. & Std. err. & p-value \\
\hline \hline Migration rate to West Germany (\%), 1991 & 0.368 & 0.343 & 0.024 & 0.034 & 0.480 \\
Migration rate to West Germany (\%), 1992 & 0.572 & 0.566 & 0.006 & 0.028 & 0.845 \\
Migration rate to West Germany (\%), 1993 & 0.596 & 0.607 & -0.011 & 0.029 & 0.704 \\
\hline
\end{tabular}

Total number of counties (Kreise): 215 (192 treatment, 23 control). P-values based on t-tests of difference in means, allowing for unequal variances. Source: own analysis based on migration matrices (by Kreis), German Federal Statistical Office. 
Table 3: Supply side: Differences across treatment regions, 1993 (county level)

\begin{tabular}{lrrrrr}
\hline Variable & Treatment & Control & Diff. & Std. err. & p-value \\
\hline \hline Food supermarkets & 0.075 & 0.070 & 0.004 & 0.015 & 0.782 \\
Mail order companies & 0.011 & 0.011 & -0.001 & 0.002 & 0.844 \\
Other retail stores & 1.767 & 1.715 & 0.052 & 0.083 & 0.544 \\
\hline
\end{tabular}

Variables are expressed as number of plants per 1000 inhabitants. Total number of counties (Kreise): 86 (75 treatment, 11 control). P-values based on t-tests of difference in means, allowing for unequal variances. Source: own analysis based on the IAB Establishment History Panel (Betriebs-Historik-Panel, BHP)

Table 4: Balancedness of covariates, EVS

\begin{tabular}{lrrrrr}
\hline Variable & Treatment & Control & Diff. & Std. Err. & p-value \\
\hline \hline Panel A: EVS 1993 & & & & & \\
\hline Disposable Income & 41268.8 & 41676.4 & -407.6 & 1028.6 & 0.692 \\
Age & 50.1 & 47.9 & -2.2 & 1 & 0.028 \\
N. of Children & 0.659 & 0.787 & -0.127 & 0.045 & 0.005 \\
Single & 0.282 & 0.246 & 0.036 & 0.023 & 0.125 \\
Female & 0.422 & 0.43 & -0.008 & 0.025 & 0.759 \\
German & 0.997 & 0.998 & -0.002 & 0.002 & 0.332 \\
Employed & 0.517 & 0.498 & 0.019 & 0.025 & 0.446 \\
Retired & 0.274 & 0.248 & 0.026 & 0.024 & 0.282 \\
On Welfare & 0.025 & 0.027 & -0.003 & 0.009 & 0.752 \\
Small City (< 5000 inh.) & 0.214 & 0.19 & 0.025 & 0.021 & 0.230 \\
\hline Panel B: EVS 1998 & \multicolumn{5}{c}{} \\
\hline Disposable Income & 49807.8 & 48201 & 1606.8 & 1106.6 & 0.147 \\
Age & 51.7 & 52.7 & -1.1 & 0.8 & 0.161 \\
N. of Children & 0.409 & 0.347 & 0.062 & 0.021 & 0.004 \\
Single & 0.303 & 0.358 & -0.055 & 0.021 & 0.008 \\
Female & 0.425 & 0.438 & -0.014 & 0.019 & 0.486 \\
German & 0.995 & 0.999 & -0.003 & 0.001 & 0.007 \\
Employed & 0.552 & 0.530 & 0.023 & 0.019 & 0.247 \\
Retired & 0.346 & 0.363 & -0.018 & 0.02 & 0.366 \\
On Welfare & 0.016 & 0.009 & 0.006 & 0.004 & 0.065 \\
Small City (< 5000 inh.) & 0.237 & 0.174 & 0.063 & 0.013 & 0.000 \\
Total number of observations: 9305 in 1993(8035 treatment, 1270 control), 11794 \\
in 1998 (10147 treatment, 1647 control). P-values based on t-tests of difference in \\
weighted means (survey weights used). & & & & \\
& & & & &
\end{tabular}


Table 5: Regression results, EVS (Income and Expenditure Survey) - Aggregate consumption behavior: Disposable Income, Total Private Consumption, and Savings

\begin{tabular}{|c|c|c|c|}
\hline $\begin{array}{r}\text { Dependent Variable } \\
(\times 100)\end{array}$ & $\begin{array}{l}\text { log Disposable } \\
\text { Income }\end{array}$ & $\begin{array}{l}\text { log Total Private } \\
\text { Consumption }\end{array}$ & $\begin{array}{c}\text { Savings }>0 \\
(0 / 1)\end{array}$ \\
\hline & (1) & (2) & (3) \\
\hline \multicolumn{4}{|l|}{ Panel A: EVS 1993} \\
\hline Treatment & $\begin{array}{l}-1.0067 \\
{[1.8651]}\end{array}$ & $\begin{array}{l}-0.8300 \\
{[1.3612]}\end{array}$ & $\begin{array}{c}0.9368 \\
{[2.2795]}\end{array}$ \\
\hline Households with positive savings (treat/control) & & & $7161(6164 / 997)$ \\
\hline Hh. with negative or zero savings (treat/control) & & & $2144(1871 / 273)$ \\
\hline N. of observations & 9305 & 9305 & 9305 \\
\hline \multicolumn{4}{|l|}{ Panel B: EVS 1998} \\
\hline Treatment & $\begin{array}{l}-2.1699 \\
{[1.9600]}\end{array}$ & $\begin{array}{c}0.6180 \\
{[1.1698]}\end{array}$ & $\begin{array}{l}-1.5009 \\
{[1.4089]}\end{array}$ \\
\hline Households with positive savings (treat/control) & & & $9086(7804 / 1282)$ \\
\hline Hh. with negative or zero savings (treat/control) & & & $2708(2343 / 365)$ \\
\hline N. of observations & 11794 & 11794 & 11794 \\
\hline
\end{tabular}

*** significant at $1 \%,{ }^{* *}$ at $5 \%,{ }^{*}$ at $10 \%$. Robust standard errors in brackets, clustered by municipality. Sampling weights used. All dependent variables multiplied by 100. All regressions include a full set of state dummies and household covariates as in Table 4, except column (1), where log disposable income is excluded from the set of regressors. Column (3) corresponds to a linear probability model. The dependent variable is defined as 1 if savings are positive, 0 otherwise. Number of municipalities: 1359 (1993), 1896 (1998). 
Table 6: Regression results, EVS (Income and Expenditure Survey) — Use of Financial Instruments

\begin{tabular}{|c|c|c|}
\hline \multirow{3}{*}{$\begin{array}{r}\text { Dependent Variable } \\
(\times 100)\end{array}$} & \multicolumn{2}{|c|}{ Interest payment $(0 / 1)$ on: } \\
\hline & Consumption Credit & Overdraft \\
\hline & (1) & (2) \\
\hline \multicolumn{3}{|l|}{ Panel A: EVS 1993} \\
\hline \multirow[t]{2}{*}{ Treatment } & 1.7287 & -1.3737 \\
\hline & [2.4061] & [1.5755] \\
\hline \multirow{2}{*}{$\begin{array}{l}\text { Households with dep. var. }=0(\text { treat } / \text { control }) \\
\text { Households with dep. var. }=1 \text { (treat } / \text { control })\end{array}$} & $6229(5352 / 877)$ & $8350(7241 / 1109)$ \\
\hline & $3067(2683 / 393)$ & $955(794 / 161)$ \\
\hline N. of observations & 9305 & 9305 \\
\hline \multicolumn{3}{|l|}{ Panel B: EVS 1998} \\
\hline \multirow[t]{2}{*}{ Treatment } & -1.4162 & -1.5388 \\
\hline & [1.7493] & [1.0312] \\
\hline \multirow{2}{*}{$\begin{array}{l}\text { Households with dep. var. }=0 \text { (treat } / \text { control }) \\
\text { Households with dep. var. }=1 \text { (treat } / \text { control })\end{array}$} & $8548(7308 / 1240)$ & $10462(9002 / 1460)$ \\
\hline & $3246(2839 / 407)$ & $1332(1145 / 187)$ \\
\hline N. of observations & 11794 & 11794 \\
\hline \multicolumn{3}{|c|}{$\begin{array}{l}\text { *** significant at } 1 \%, * * \text { at } 5 \%, * \text { at } 10 \% \text {. Robust standard errors in brackets, clustered by } \\
\text { household. Sampling weights used. The dependent variable is defined as } 1 \text { if interest pay- } \\
\text { ments are positive, } 0 \text { if absent. All dependent variables multiplied by } 100 \text {. All regressions } \\
\text { include a full set of household covariates as in Table } 4 \text { and state dummies. Number of mu- } \\
\text { nicipalities: } 1359(1993), 1896(1998) \text {. }\end{array}$} \\
\hline
\end{tabular}

Table 7: Most and least advertised categories of goods

\begin{tabular}{lrrr}
\hline Goods & $\begin{array}{r}\text { Avg. minutes of } \\
\text { advertising per day }\end{array}$ & $\begin{array}{r}\text { Share of advertising } \\
\text { time (\%) }\end{array}$ & $\begin{array}{r}\text { Avg. budget share } \\
\text { in 1993 (\%) }\end{array}$ \\
\hline \hline Food and drinks & $6^{\prime} 49^{\prime \prime}$ & 42.5 & 23.7 \\
Body and mouth care & $2^{\prime} 52^{\prime \prime}$ & 17.9 & 3.4 \\
Cleaning and washing & $1^{\prime} 46^{\prime \prime}$ & 11 & 0.7 \\
Media, leisure & $0^{\prime} 53^{\prime \prime}$ & 5.47 & 6.3 \\
Home and garden & $0^{\prime} 35^{\prime \prime}$ & 3.66 & 11.7 \\
Pharmaceuticals & $0^{\prime} 31^{\prime \prime}$ & 3.19 & 0.7 \\
Cars, accessories & $0^{\prime} 28^{\prime \prime}$ & 2.95 & 14.1 \\
Transportation and tourism & $0^{\prime} 11^{\prime \prime}$ & 1.15 & 5.9 \\
Photo, optics, watches, jewelry & $0^{\prime} 8^{\prime \prime}$ & 0.83 & 1.1 \\
Clothes, textiles & $0^{\prime} 8^{\prime \prime}$ & 0.78 & 8.4 \\
Other & $0^{\prime} 0^{\prime \prime}$ & 0 & 24.1 \\
\hline
\end{tabular}

Figures correspond to advertising time allocated to each one of the categories of goods on the main West German state TV channel (ARD); average of the years 1980-89. Source: Zentralausschuss der Werbewirtschaft, ed. (1981-1990). 
Table 8: Regression results, EVS (Income and Expenditure Survey) — Recomposition of consumption

\begin{tabular}{|c|c|c|c|c|c|}
\hline \multirow{3}{*}{$\begin{array}{l}\text { Dependent variable: } \\
\text { Treatment definition: }\end{array}$} & \multicolumn{5}{|c|}{$100 \times \log (1+$ expenditures $)$} \\
\hline & \multicolumn{4}{|c|}{ Binary } & \multirow{2}{*}{$\frac{\text { Continuous }}{(5)}$} \\
\hline & (1) & (2) & (3) & (4) & \\
\hline \multicolumn{6}{|l|}{ Panel A: EVS 1993} \\
\hline \multirow[b]{3}{*}{ Treatment $\times$ Advertising } & $\begin{array}{c}16.549^{* * *} \\
{[0.388]}\end{array}$ & $\begin{array}{c}16.549^{* * *} \\
{[0.388]}\end{array}$ & $\begin{array}{c}2.653^{* * *} \\
{[0.062]}\end{array}$ & $\begin{array}{c}29.142^{* * *} \\
{[0.824]}\end{array}$ & $\begin{array}{c}16.071^{* * *} \\
{[0.495]}\end{array}$ \\
\hline & $\begin{array}{c}-8.96 \\
{[5.951]}\end{array}$ & $\begin{array}{l}-4.569 \\
{[2.899]}\end{array}$ & $\begin{array}{l}-8.96 \\
{[5.951]}\end{array}$ & $\begin{array}{c}-9.382 \\
{[5.802]}\end{array}$ & $\begin{array}{c}-14.267^{*} \\
{[7.472]}\end{array}$ \\
\hline & $\begin{array}{l}1.537^{* * * *} \\
{[0.547]}\end{array}$ & $\begin{array}{l}1.537^{* * *} \\
{[0.547]}\end{array}$ & $\begin{array}{c}0.246^{* * *} \\
{[0.088]}\end{array}$ & $\begin{array}{l}1.979 * * \\
{[1.000]}\end{array}$ & $\begin{array}{l}2.132^{* * *} \\
{[0.714]}\end{array}$ \\
\hline $\begin{array}{l}\text { N. of observations } \\
\text { N. of households }\end{array}$ & $\begin{array}{c}102355 \\
9305\end{array}$ & $\begin{array}{c}102355 \\
9305\end{array}$ & $\begin{array}{c}102355 \\
9305\end{array}$ & $\begin{array}{c}102355 \\
9305\end{array}$ & $\begin{array}{c}102355 \\
9305\end{array}$ \\
\hline \multicolumn{6}{|l|}{ Panel B: EVS 1998} \\
\hline Advertising & $\begin{array}{c}3.398^{* * *} \\
{[0.239]}\end{array}$ & $\begin{array}{c}3.398^{* * *} \\
{[0.239]}\end{array}$ & $\begin{array}{c}0.545^{* * *} \\
{[0.038]}\end{array}$ & $\begin{array}{c}21.637^{* * *} \\
{[0.759]}\end{array}$ & $\begin{array}{l}3.518^{* * *} \\
{[0.296]}\end{array}$ \\
\hline Treatment & $\begin{array}{c}3.989 \\
{[4.656]}\end{array}$ & $\begin{array}{l}-1.068 \\
{[1.607]}\end{array}$ & $\begin{array}{c}3.989 \\
{[4.657]}\end{array}$ & $\begin{array}{l}-0.833 \\
{[3.254]}\end{array}$ & $\begin{array}{c}2.155 \\
{[5.039]}\end{array}$ \\
\hline Treatment $\times$ Advertising & $\begin{array}{c}0.197 \\
{[0.284]}\end{array}$ & $\begin{array}{c}0.197 \\
{[0.284]}\end{array}$ & $\begin{array}{c}0.032 \\
{[0.046]}\end{array}$ & $\begin{array}{c}1.234 \\
{[0.815]}\end{array}$ & $\begin{array}{c}0.059 \\
{[0.355]}\end{array}$ \\
\hline N. of observations & 129734 & 129734 & 129734 & 129734 & 129734 \\
\hline N. of households & 11794 & 11794 & 11794 & 11794 & 11794 \\
\hline $\begin{array}{l}\text { Household covariates } \\
\text { Advertising definition } \\
\text { Regression weights }\end{array}$ & $\underset{S \times B}{N}$ & $\begin{array}{c}\mathrm{Y} \\
\min p . d \\
S \times B\end{array}$ & $\begin{array}{l}\mathrm{N} \\
\text { share } \\
\mathrm{S} \times \mathrm{B}\end{array}$ & $\underset{S}{\mathrm{~N}}$ & $\begin{array}{c}\mathrm{N} \\
\min p . d . \\
S \times B\end{array}$ \\
\hline
\end{tabular}

*** significant at $1 \%,{ }^{* *}$ at $5 \%,{ }^{*}$ at $10 \%$. Robust standard errors in brackets, clustered by municipality. Sampling weights used. Regressions are weighted either by the EVS sampling weights (S), or additionally also by the budget share of each category of consumption goods $(\mathrm{S} \times \mathrm{B})$. The regression in column (3) uses the share of advertising time, rather than minutes of advertising per day, as explanatory variable (cf. Table 7 ). Household covariates included in column (2) are listed in Table 4. Number of municipalities: 1359 (1993), 1896 (1998). 
Table 9: Regression results, EVS — Recomposition of consumption: Robustness

\begin{tabular}{|c|c|c|c|c|c|}
\hline \multirow[t]{4}{*}{ Dependent Variable: } & \multicolumn{5}{|c|}{$100 \times \log (1+$ expenditures $)$} \\
\hline & \multirow{3}{*}{$\begin{array}{c}\begin{array}{c}\text { Household } \\
\text { clustering }\end{array} \\
(1) \\
\end{array}$} & \multirow{3}{*}{$\begin{array}{c}\begin{array}{c}\text { Including } \\
\text { East Berlin }\end{array} \\
(2)\end{array}$} & \multicolumn{3}{|c|}{ "Treatment" threshold: } \\
\hline & & & $-84.8 \mathrm{~dB}$ & $-82.8 \mathrm{~dB}$ & $-80.8 \mathrm{~dB}$ \\
\hline & & & (3) & (4) & (5) \\
\hline \multicolumn{6}{|l|}{ Panel A: EVS 1993} \\
\hline Advertising & $\begin{array}{c}16.549^{* * *} \\
{[0.512]}\end{array}$ & $\begin{array}{c}16.549^{* * *} \\
{[0.388]}\end{array}$ & $\begin{array}{c}16.605^{* * *} \\
{[0.369]}\end{array}$ & $\begin{array}{c}16.532^{* * *} \\
{[0.349]}\end{array}$ & $\begin{array}{c}16.663^{* * *} \\
{[0.339]}\end{array}$ \\
\hline Treatment & $\begin{array}{l}-8.960^{*} \\
{[5.327]}\end{array}$ & $\begin{array}{c}-10.559^{*} \\
{[5.901]}\end{array}$ & $\begin{array}{l}-8.846 \\
{[5.718]}\end{array}$ & $\begin{array}{c}-10.664^{*} \\
{[5.714]}\end{array}$ & $\begin{array}{c}-10.845^{* *} \\
{[5.526]}\end{array}$ \\
\hline Treatment $\times$ Advertising & $\begin{array}{l}1.537^{* * * *} \\
{[0.571]}\end{array}$ & $\begin{array}{c}1.583^{* * *} \\
{[0.522]}\end{array}$ & $\begin{array}{c}1.530^{* * *} \\
{[0.544]}\end{array}$ & $\begin{array}{c}1.641^{* * *} \\
{[0.535]}\end{array}$ & $\begin{array}{c}1.531^{* * *} \\
{[0.537]}\end{array}$ \\
\hline N. of observations & 102355 & 111056 & 102355 & 102355 & 102355 \\
\hline N. of households & 9305 & 11096 & 9305 & 9305 & 9305 \\
\hline N. of households in treatment region & 8035 & 9826 & 7752 & 7639 & 7404 \\
\hline \multicolumn{6}{|l|}{ Panel B: EVS 1998} \\
\hline Advertising & $\begin{array}{c}3.398^{* * *} \\
{[0.355]}\end{array}$ & $\begin{array}{c}3.398^{* * *} \\
{[0.239]}\end{array}$ & $\begin{array}{c}3.610^{* * *} \\
{[0.257]}\end{array}$ & $\begin{array}{c}3.592^{* * *} \\
{[0.243]}\end{array}$ & $\begin{array}{c}3.484^{* * *} \\
{[0.249]}\end{array}$ \\
\hline Treatment & 3.989 & 3.808 & 3.197 & 2.486 & 1.189 \\
\hline Treatment $\times$ Advertising & 0.197 & 0.052 & -0.049 & -0.028 & 0.106 \\
\hline & {$[0.381]$} & {$[0.305]$} & {$[0.301]$} & [0.291] & [0.296] \\
\hline N. of observations & 129734 & 141966 & 129734 & 129734 & 129734 \\
\hline N. of households & 11794 & 12906 & 11794 & 11794 & 11794 \\
\hline N. of households in treatment region & 10147 & 11259 & 9787 & 9598 & 9317 \\
\hline
\end{tabular}

*** significant at $1 \%,{ }^{* *}$ at $5 \%,{ }^{*}$ at $10 \%$. Robust standard errors in brackets, clustered by municipality (by household in column (1)). All regressions use the binary treatment definition and are weighted by EVS sampling weights and budget shares. Advertising defined as minutes per day (cf. Table 7). Number of municipalities: 1359 (1993), 1896 (1998). 
Table 10: Regression results, EVS — Recomposition of consumption: Subsamples

\begin{tabular}{|c|c|c|c|}
\hline \multirow{3}{*}{$\begin{array}{r}\text { Dependent Variable: } \\
\text { Sample: }\end{array}$} & \multicolumn{3}{|c|}{$100 \times \log (1+$ expenditures $)$} \\
\hline & $\begin{array}{c}-86.8 \mathrm{~dB} \\
\pm 30 \mathrm{~dB}\end{array}$ & $\begin{array}{c}-86.8 \mathrm{~dB} \\
\pm 20 \mathrm{~dB}\end{array}$ & $\begin{array}{c}-86.8 \mathrm{~dB} \\
\pm 10 \mathrm{~dB}\end{array}$ \\
\hline & (1) & (2) & (3) \\
\hline \multicolumn{4}{|l|}{ Panel A: EVS 1993} \\
\hline Advertising & $\begin{array}{c}16.699^{* * *} \\
{[0.389]}\end{array}$ & $\begin{array}{c}16.596^{* * *} \\
{[0.390]}\end{array}$ & $\begin{array}{c}16.870^{* * *} \\
{[0.401]}\end{array}$ \\
\hline Treatment & $\begin{array}{c}-11.872^{* *} \\
{[6.045]}\end{array}$ & $\begin{array}{l}-10.164 \\
{[6.779]}\end{array}$ & $\begin{array}{c}5.496 \\
{[7.814]}\end{array}$ \\
\hline Treatment $\times$ Advertising & $\begin{array}{c}1.662^{* * *} \\
{[0.584]}\end{array}$ & $\begin{array}{l}1.510^{* *} \\
{[0.698]}\end{array}$ & $\begin{array}{c}-0.326 \\
{[0.791]}\end{array}$ \\
\hline $\begin{array}{r}\text { N. of observations } \\
\text { N. of households }\end{array}$ & $\begin{array}{c}72842 \\
6622\end{array}$ & $\begin{array}{c}53405 \\
4855\end{array}$ & $\begin{array}{c}26081 \\
2371\end{array}$ \\
\hline N. of municipalities & 912 & 664 & 391 \\
\hline \multicolumn{4}{|l|}{ Panel B: EVS 1998} \\
\hline Advertising & $\begin{array}{c}3.565^{* * *} \\
{[0.230]}\end{array}$ & $\begin{array}{c}3.434^{* * *} \\
{[0.222]}\end{array}$ & $\begin{array}{c}3.112^{* * *} \\
{[0.229]}\end{array}$ \\
\hline Treatment & $\begin{array}{c}1.037 \\
{[5.029]}\end{array}$ & $\begin{array}{c}0.157 \\
{[5.171]}\end{array}$ & $\begin{array}{c}6.901 \\
{[5.552]}\end{array}$ \\
\hline Treatment $\times$ Advertising & $\begin{array}{c}0.368 \\
{[0.309]}\end{array}$ & $\begin{array}{l}0.646^{* * *} \\
{[0.328]}\end{array}$ & $\begin{array}{c}0.144 \\
{[0.433]}\end{array}$ \\
\hline N. of observations & 87571 & 65626 & 34078 \\
\hline N. of households & 7961 & 5966 & 3098 \\
\hline N. of municipalities & 1158 & 829 & 488 \\
\hline
\end{tabular}

*** significant at $1 \%,{ }^{* *}$ at $5 \%,{ }^{*}$ at $10 \%$. Robust standard errors in brackets, clustered by municipality. All regressions use the binary treatment definition and are weighted by EVS sampling weights and budget shares. Advertising defined as minutes per day (cf. Table 7). 
Table 11: Regression results, EVS — Recomposition: Robustness to Distance

\begin{tabular}{|c|c|c|}
\hline \multirow[t]{3}{*}{ Dependent Variable } & \multicolumn{2}{|c|}{$100 \times \log (1+$ expenditures } \\
\hline & $\begin{array}{l}\text { Whole } \\
\text { sample }\end{array}$ & $\begin{array}{l}\text { Treatment } \\
\text { region }\end{array}$ \\
\hline & (1) & (2) \\
\hline \multicolumn{3}{|l|}{ Panel A: EVS 1993} \\
\hline Advertising & $\begin{array}{c}16.907^{* * * *} \\
{[1.388]}\end{array}$ & $\begin{array}{c}18.237^{* * *} \\
{[0.906]}\end{array}$ \\
\hline Treatment & $\begin{array}{l}-9.763 \\
{[7.718]}\end{array}$ & $\cdot$ \\
\hline Treatment $\times$ Advertising & $\begin{array}{l}1.357^{*} \\
{[0.762]}\end{array}$ & . \\
\hline Distance & $\begin{array}{l}-0.914 \\
{[7.364]}\end{array}$ & $\begin{array}{l}-1.702 \\
{[7.831]}\end{array}$ \\
\hline Distance $\times$ Advertising & $\begin{array}{l}-0.205 \\
{[0.765]}\end{array}$ & $\begin{array}{c}-0.173 \\
{[0.815]}\end{array}$ \\
\hline N. of observations & 102355 & 88385 \\
\hline N. of households & 9305 & 8035 \\
\hline N. of municipalities & 1359 & 1194 \\
\hline \multicolumn{3}{|l|}{ Panel B: EVS 1998} \\
\hline Advertising & $\begin{array}{c}3.184^{* * *} \\
{[0.576]}\end{array}$ & $\begin{array}{c}3.432^{* * *} \\
{[0.315]}\end{array}$ \\
\hline Treatment & $\begin{array}{c}0.159 \\
{[5.582]}\end{array}$ & . \\
\hline Treatment $\times$ Advertising & $\begin{array}{c}0.307 \\
{[0.385]}\end{array}$ & . \\
\hline Distance & $\begin{array}{l}-4.309 \\
{[3.240]}\end{array}$ & $\begin{array}{l}-4.928 \\
{[3.390]}\end{array}$ \\
\hline Distance $\times$ Advertising & $\begin{array}{c}0.123 \\
{[0.300]}\end{array}$ & $\begin{array}{c}0.193 \\
{[0.313]}\end{array}$ \\
\hline $\begin{array}{l}\text { N. of observations } \\
\text { N. of households }\end{array}$ & $\begin{array}{c}129734 \\
11794\end{array}$ & $\begin{array}{c}111617 \\
10147\end{array}$ \\
\hline N. of municipalities & 1896 & 1682 \\
\hline
\end{tabular}

$\overline{* * *}$ significant at $1 \%,{ }^{* *}$ at $5 \%,{ }^{*}$ at $10 \%$. Robust standard errors in brackets, clustered by household. All regressions use the binary treatment definition and are weighted by EVS sampling weights and budget shares. Advertising defined as minutes per day (cf. Table 7). Distance to West Germany measured in km. 


\section{A Supplemental Appendix: Additional tables (NOT FOR PUBLICA- TION)}

\section{A.1 Construction of the treatment indicator}

Table A.1: West German Antennas (ARD)

\begin{tabular}{llrrrr}
\hline Location & Coordinates & Altitude & Height & Power & Frequency \\
\hline \hline Bungsberg, NDR-Mast & $54^{\circ} 13^{\prime} 0^{\prime \prime} \mathrm{N}, 10^{\circ} 43^{\prime} 8^{\prime \prime} \mathrm{E}$ & 136 & 154 & 260 & 703.25 \\
Neumünster & $53^{\circ} 58^{\prime} 46^{\prime \prime} \mathrm{N}, 9^{\circ} 50^{\prime} 59^{\prime \prime} \mathrm{E}$ & 27 & 141 & 500 & 527.25 \\
Hamburg-Moorfleet & $53^{\circ} 31^{\prime} 9^{\prime \prime} \mathrm{N}, 10^{\circ} 6^{\prime} 10^{\prime \prime} \mathrm{E}$ & 1 & 264 & 500 & 751.25 \\
Hamburg-Moorfleet & $53^{\circ} 31^{\prime} 9^{\prime \prime} \mathrm{N}, 10^{\circ} 6^{\prime} 10^{\prime \prime} \mathrm{E}$ & 1 & 264 & 100 & 203.25 \\
Dannenberg/Zernien & $53^{\circ} 3^{\prime} 56^{\prime \prime} \mathrm{N}, 10^{\circ} 53^{\prime} 50^{\prime \prime} \mathrm{E}$ & 102 & 234 & 250 & 647.25 \\
Scholzplatz, Berlin (West) & $52^{\circ} 30^{\prime} 22^{\prime \prime} \mathrm{N}, 13^{\circ} 13^{\prime} 10^{\prime \prime} \mathrm{E}$ & 66 & 220 & 100 & 189.25 \\
Tofhaus/Harz-West & $51^{\circ} 48^{\prime} 6^{\prime \prime} \mathrm{N}, 10^{\circ} 31^{\prime} 56^{\prime \prime} \mathrm{E}$ & 820 & 243 & 100 & 210.25 \\
Rimberg & $50^{\circ} 47^{\prime} 51^{\prime \prime} \mathrm{N}, 9^{\circ} 27^{\prime} 41^{\prime \prime} \mathrm{E}$ & 572 & 155 & 400 & 759.25 \\
Hoher Meißner & $51^{\circ} 13^{\prime} 42^{\prime \prime} \mathrm{N}, 9^{\circ} 51^{\prime} 50^{\prime \prime} \mathrm{E}$ & 705 & 155 & 100 & 189.25 \\
Kreuzberg (Rhön) & $50^{\circ} 22^{\prime} 12^{\prime \prime} \mathrm{N}, 9^{\circ} 58^{\prime} 48^{\prime \prime} \mathrm{E}$ & 927 & 182 & 100 & 55.25 \\
Ochsenkopf & $50^{\circ} 1^{\prime} 50^{\prime \prime} \mathrm{N}, 11^{\circ} 48^{\prime} 29^{\prime \prime} \mathrm{E}$ & 990 & 160 & 100 & 62.25 \\
Hoher Bogen & $49^{\circ} 14^{\prime} 57^{\prime \prime} \mathrm{N}, 12^{\circ} 53^{\prime} 27^{\prime \prime} \mathrm{E}$ & 976 & 70 & 500 & 743.25 \\
\hline
\end{tabular}

Source: Norddeutscher Rundfunk, ed. (1989). Altitude and height of the antenna mast in meters. Power in kW. Frequency in MHz.

\section{A.2 Definition of treatment area}

Based on the antenna data above, we calculate average signal strength of the main West German TV broadcaster, ARD, in each one of the municipalities in East Germany (7529 municipalities in 1993, 5793 municipalities in 1998). These data are then used to define the treatment region in the EVS (Income and Expenditure Survey): municipalities with an average signal strength higher than $-86.8 \mathrm{~dB}$ (the average level in Dresden) are defined as "treated".

In other data sets observations may not be coded at the municipality level. Official data from the Statistical Yearbooks of the GDR is mostly available at the level of Bezirke (districts; 15 in East Germany as of 1990). Figures 1 and 3 show the boundaries of these districts (a list of the districts can be found in Table A.2). The analysis in Table 1 is based on district-level data. We define the districts of Dresden (south-east), Neubrandenburg and Rostock (north-east) as treated (cf. Figure 3).

Official migration statistics (as used in Tables 2 and A.3) are defined at the level of Kreise (counties). In the years until 1994, there were 215 Kreise in East Germany. We consider a Kreis as treated if average signal strength is higher than $-86.8 \mathrm{~dB}$. This yields the following 23 Kreise in the control area (listed in descending order of signal strength): Dresden Stadt, Altentreptow, Niesky, Anklam, Ribnitz-Damgarten, Malchin, Bautzen, Neubrandenburg Stadt, Ueckermünde, Teterow, Löbau, Pirna, Greifswald Land, Demmin, Görlitz Land, Grimmen, Wolgast, Greifswald Stadt, Zittau, Görlitz Stadt, Stralsund Land, Stralsund Stadt, Rügen. 
The IAB's census of plants (Establishment History Panel, BHP) used in Table 3 has a variable indicating in which Kreis each plant/establishment is located. However, the county borders used in this context are the ones as of 2008. Due to several waves of county redistricting which occurred after 1994, there were only 86 Kreise left in East Germany as of 2008. Applying the same criteria as above, we obtain the following list of 11 Kreise in the control region: Dresden Stadt, Neubrandenburg Stadt, Greifswald Stadt, Stralsund Stadt, Rügen, Demmin, Nordvorpommern, Ostvorpommern, Uecker-Randow, Görlitz, Sächsische Schweiz-Osterzgebirge.

Table A.2: States and districts in East Germany

\begin{tabular}{|c|c|}
\hline State (Bundesland) & District (Bezirk) \\
\hline Mecklenburg-Vorpommern & $\begin{array}{l}\text { Neubrandenburg* } \\
\text { Rostock* } \\
\text { Schwerin }\end{array}$ \\
\hline Sachsen-Anhalt & $\begin{array}{l}\text { Halle } \\
\text { Magdeburg }\end{array}$ \\
\hline Brandenburg & $\begin{array}{l}\text { Cottbus } \\
\text { Frankfurt/Oder } \\
\text { Potsdam }\end{array}$ \\
\hline Thüringen & $\begin{array}{l}\text { Erfurt } \\
\text { Gera } \\
\text { Suhl }\end{array}$ \\
\hline Sachsen & $\begin{array}{l}\text { Dresden* } \\
\text { Karl-Marx-Stadt (Chemnitz) } \\
\text { Leipzig }\end{array}$ \\
\hline Berlin & Berlin (East) \\
\hline $\begin{array}{l}\text { Districts were the administr } \\
\text { 1990, states are the administra } \\
\text { Germany after 1990). The co } \\
\text { and states is only approximat } \\
\text { in the control area (i.e., not co }\end{array}$ & $\begin{array}{l}\text { tive units of the GDR before } \\
\text { tive divisions of the FRG (East } \\
\text { respondence between districts } \\
\text {. Asterisks }\left({ }^{*}\right) \text { denote districts } \\
\text { ered by West German TV). }\end{array}$ \\
\hline
\end{tabular}




\section{A.3 Migration data, 1991-1993}

Table A.3 displays total migration rates between 1991 and 1993 from treatment and control areas and the breakdown of these rates by destination (Berlin, West Germany, control region, and treatment region). The numbers capture the moves of people that move out of their Kreis (district) of residence to another Kreis (they do not capture moves within the same Kreis).

The table suggests that total migration rates were low and similar in treatment and control areas (considerably higher rates were recorded in the years 1989 and 1990; see Hunt, 2006. However, there is no breakdown of migration by place of origin available for those years, so that one cannot compare migration rates by treatment region). The migration rates to areas outside of East Germany (i.e., Berlin and West Germany) were again similar when comparing control and treatment regions. We observe that migration rates from control to treatment areas were higher than from treatment to control areas, since the treatment area is much larger than the control area (about 10\% of the population in East Germany lived in the control area).

Table A.3: Migration matrix, 1991-1993

\begin{tabular}{lrrrrrr}
\hline Origin & Total & \multicolumn{3}{c}{ by destination: } & Population \\
\cline { 3 - 6 } & & Berlin & $\begin{array}{c}\text { East Germany, } \\
\text { Treatment }\end{array}$ & $\begin{array}{c}\text { East Germany, } \\
\text { Control }\end{array}$ & $\begin{array}{c}\text { West } \\
\text { Germany }\end{array}$ & \\
\hline East Germany, & 821,873 & 43,106 & 546,684 & 30,981 & 201,102 & $12,873,985$ \\
Treatment & $(6.38 \%)$ & $(0.33 \%)$ & $(4.25 \%)$ & $(0.24 \%)$ & $(1.56 \%)$ & \\
East Germany, & 100,934 & 4,141 & 32,421 & 36,640 & 27,732 & $1,634,665$ \\
Control & $(6.17 \%)$ & $(0.25 \%)$ & $(1.98 \%)$ & $(2.24 \%)$ & $(1.7 \%)$ & \\
\hline
\end{tabular}

Population figures refer to 1991. Figures in italics express the total number of people moving across county borders from 1991 to 1993, relatively to original population size in 1991. Source: own analysis based on migration matrices (by Kreis), German Federal Statistical Office.

In Table A.4 we show how total outmigration rates from East Germany to West Germany differed by treatment region and age category. Differential outmigration by age could be problematic if the response to "treatment" through West German media varies by age. The analysis below shows, however, that outmigration rates were similar in treatment and control regions across all age categories. 
Table A.4: Migration rates 1991-1993 (county level), by age and treatment status

\begin{tabular}{|c|c|c|c|c|c|}
\hline Variable: & & & & & \\
\hline $\begin{array}{l}\text { Migration rate to West Germany, } 1991-1993 \\
\text { in \% of original population aged: }\end{array}$ & Treatment & Control & Diff. & Std. err. & p-value \\
\hline below 18 & 1.047 & 1.035 & 0.012 & 0.076 & 0.870 \\
\hline $18-25$ & 4.679 & 4.704 & -0.025 & 0.235 & 0.917 \\
\hline $25-30$ & 3.636 & 3.486 & 0.150 & 0.184 & 0.420 \\
\hline $30-50$ & 1.731 & 1.617 & 0.114 & 0.11 & 0.306 \\
\hline $50-65$ & 0.447 & 0.486 & -0.039 & 0.034 & 0.262 \\
\hline above 65 & 0.358 & 0.407 & -0.049 & 0.039 & 0.227 \\
\hline
\end{tabular}




\section{A.4 Differences in consumption levels and advertising}

Table A.5 presents the data underlying Figures 5 and 6.

Table A.5: Differences in consumption levels and advertising: Raw data

\begin{tabular}{|c|c|c|c|c|c|c|}
\hline Goods & Treatment & Control & Difference & Std.err. & $\begin{array}{r}\text { Share of } \\
\text { advertising } \\
\text { time }(\%)\end{array}$ & $\begin{array}{r}\text { Avg. } \\
\text { budget } \\
\text { share }(\%)\end{array}$ \\
\hline \multicolumn{7}{|l|}{ Panel A: EVS 1993} \\
\hline Food and drinks & 8.826 & 8.812 & 0.014 & 0.031 & 42.5 & 23.7 \\
\hline Body and mouth care & 6.558 & 6.568 & -0.010 & 0.067 & 17.89 & 3.4 \\
\hline Cleaning and washing & 4.774 & 4.754 & 0.020 & 0.097 & 11 & 0.7 \\
\hline Media, leisure & 7.248 & 7.345 & -0.096 & 0.044 & 5.47 & 6.3 \\
\hline Home and garden & 7.645 & 7.636 & 0.008 & 0.065 & 3.66 & 11.7 \\
\hline Pharmaceuticals & 3.125 & 3.213 & -0.088 & 0.131 & 3.19 & 0.7 \\
\hline Cras, accessories & 5.960 & 6.122 & -0.162 & 0.182 & 2.95 & 14.1 \\
\hline Transportation and tourism & 6.347 & 6.717 & -0.370 & 0.107 & 1.15 & 5.9 \\
\hline Photo, optics, watches, and jewelry & 4.165 & 4.112 & 0.053 & 0.127 & 0.83 & 1.1 \\
\hline Clothes and textiles & 7.505 & 7.601 & -0.096 & 0.048 & 0.78 & 8.4 \\
\hline All other & 8.908 & 8.930 & -0.022 & 0.022 & 0 & 24.1 \\
\hline \multicolumn{7}{|l|}{ Panel B: EVS 1998} \\
\hline Food and drinks & 7.231 & 7.178 & 0.053 & 0.024 & 42.5 & 15.5 \\
\hline Body and mouth care & 4.953 & 4.935 & 0.017 & 0.049 & 17.89 & 2.3 \\
\hline Cleaning and washing & 3.532 & 3.430 & 0.103 & 0.060 & 11 & 0.6 \\
\hline Media, leisure & 6.082 & 6.117 & -0.035 & 0.036 & 5.47 & 6.2 \\
\hline Home and garden & 5.940 & 5.896 & 0.043 & 0.059 & 3.66 & 9.4 \\
\hline Pharmaceuticals & 3.681 & 3.688 & -0.007 & 0.072 & 3.19 & 0.9 \\
\hline Cars, accessories & 4.939 & 4.728 & 0.211 & 0.136 & 2.95 & 12.9 \\
\hline Transportation and tourism & 4.206 & 4.632 & -0.426 & 0.092 & 1.15 & 6.3 \\
\hline Photo, optics, watches, jewelry & 3.254 & 3.313 & -0.060 & 0.087 & 0.83 & 1.2 \\
\hline Clothes, textiles & 5.838 & 5.715 & 0.123 & 0.067 & 0.78 & 6.1 \\
\hline Other & 8.173 & 8.110 & 0.063 & 0.021 & 0 & 38.6 \\
\hline
\end{tabular}

Figures correspond to the logarithm of average consumption expenditures of all households in the respective regions. Refer also to the notes to Figures 5 and 6 and Table 7. 


\section{A.5 Additional robustness checks}

\section{A.5.1 Clustering levels}

Consumption patterns could be correlated even across households located in different, neighboring municipalities. That is why our default level of clustering in the regressions (clustering at the municipality level) could be missing some patterns of correlation in the error terms.

Unfortunately, due to confidentiality reasons we do not know the exact coordinates of the municipalities of the households in the dataset and thus we cannot group neighboring municipalities together. As an alternative approach, we divide each of the five post-Reunification states (Länder) of East Germany into cells corresponding to 1, 3, 5 or $10 \mathrm{~dB}$ of signal strength. For example, in the last case, we would divide Saxony into 9 cells corresponding to signal strengths of $(-106.8 ;-96.8]$, $(-96.8 ;-86.8],(-86.8 ;-76.8],(-76.8 ;-66.8] \mathrm{dB}$ etc. Even though some households in the same cell may lie in disjoint regions, in most cases one cell would consist of adjacent municipalities.

This method results in a number of clusters varying between approximately 300 ( $1 \mathrm{~dB}$ cells) and 40 (10dB cells). Results in Table A.6 below, based on our baseline regression of Table 8, column 1 , show that the aggregation of households into larger clusters does not affect the precision of our estimates. In all cases (with the possible exception of the case of $10 \mathrm{~dB}$ cells) the number of resulting clusters is safely above the threshold suggested by Cameron et al. (2008), allaying fears of overrejection of null hypotheses.

\section{A.5.2 Omitting selected categories of consumption goods}

Another concern could be the role of single categories of goods in our analysis. As evident in Figures 5 and 6, some categories of goods are responsible for a large share of the advertising time (most notably, food and drinks, body and mouth care, and cleaning and washing products), whereas other categories have almost no advertising. In table A.7, we replicate the baseline regression of Table 8, column 1, omitting each one of the categories of consumption goods: starting in column (1) with the goods with zero advertising and ending in column (11), which leaves out food and drinks (columns are sorted in increasing intensity of advertising for the omitted category).

The results are reassuring: point estimates on the interaction term of interest (Treatment $\times$ Advertising) are mostly unchanged in magnitude and significance. In column (11) we drop the category with the highest intensity of advertising ( $42.5 \%$ of advertising time) and with the secondlargest budget share (15.46\%), food and drinks. Even in this case, the magnitude of the point estimate is preserved at 1.927 (compared to the baseline estimate of 1.537), even though the larger standard error reduces the p-value to 0.32 .

\section{A.5.3 Use of the continuous treatment definition}

Tables A.8 and A.9 replicate all the results of the main paper using, where applicable, the continuous treatment definition instead of the threshold-based one. This alternative definition confirms all results of the analysis in both magnitude and significance. 
Table A.6: Regression results, EVS — Recomposition of consumption: Clustering

\begin{tabular}{|c|c|c|c|c|}
\hline \multirow{3}{*}{$\begin{array}{r}\text { Dependent Variable: } \\
\text { Clustering level }\end{array}$} & \multicolumn{4}{|c|}{$100 \times \log (1+$ expenditures $)$} \\
\hline & $\begin{array}{c}1 \mathrm{~dB} \text { cells } \times \\
\text { state dummies }\end{array}$ & $\begin{array}{c}\text { 3dB cells } \times \\
\text { state dummies }\end{array}$ & $\begin{array}{c}5 \mathrm{~dB} \text { cells } \times \\
\text { state dummies }\end{array}$ & $\begin{array}{l}10 \mathrm{~dB} \text { cells } \times \\
\text { state dummies }\end{array}$ \\
\hline & (1) & (2) & (3) & (4) \\
\hline \multicolumn{5}{|l|}{ Panel A: EVS 1993} \\
\hline Advertising & $\begin{array}{c}16.549^{* * *} \\
{[0.427]}\end{array}$ & $\begin{array}{c}16.549^{* * *} \\
{[0.455]}\end{array}$ & $\begin{array}{c}16.549^{* * *} \\
{[0.296]}\end{array}$ & $\begin{array}{c}16.549^{* * *} \\
{[0.285]}\end{array}$ \\
\hline Treatment & $\begin{array}{l}-8.960 \\
{[5.706]}\end{array}$ & $\begin{array}{l}-8.960 \\
{[5.533]}\end{array}$ & $\begin{array}{l}-8.960 \\
{[5.609]}\end{array}$ & $\begin{array}{l}-8.960 \\
{[6.386]}\end{array}$ \\
\hline Treatment $\times$ Advertising & $\begin{array}{l}1.537^{* * * *} \\
{[0.593]}\end{array}$ & $\begin{array}{l}1.537^{* *} \\
{[0.626]}\end{array}$ & $\begin{array}{c}1.537^{* * *} \\
{[0.568]}\end{array}$ & $\begin{array}{l}1.537^{* * * *} \\
{[0.531]}\end{array}$ \\
\hline N. of observations & 102355 & 102355 & 102355 & 102355 \\
\hline N. of households & 9305 & 9305 & 9305 & 9305 \\
\hline N. of clusters & 296 & 119 & 75 & 40 \\
\hline \multicolumn{5}{|l|}{ Panel B: EVS 1998} \\
\hline Advertising & $\begin{array}{c}3.398^{* * *} \\
{[0.264]}\end{array}$ & $\begin{array}{c}3.398^{* * *} \\
{[0.315]}\end{array}$ & $\begin{array}{c}3.398^{* * *} \\
{[0.312]}\end{array}$ & $\begin{array}{c}3.398^{* * *} \\
{[0.381]}\end{array}$ \\
\hline Treatment & $\begin{array}{c}3.989 \\
{[4.845]}\end{array}$ & $\begin{array}{c}3.989 \\
{[2.882]}\end{array}$ & $\begin{array}{c}3.989 \\
{[2.893]}\end{array}$ & $\begin{array}{l}3.989 \\
{[2.890]}\end{array}$ \\
\hline Treatment $\times$ Advertising & $\begin{array}{c}0.197 \\
{[0.308]}\end{array}$ & $\begin{array}{c}0.197 \\
{[0.361]}\end{array}$ & $\begin{array}{c}0.197 \\
{[0.358]}\end{array}$ & $\begin{array}{c}0.197 \\
{[0.425]}\end{array}$ \\
\hline N. of observations & 129734 & 129734 & 129734 & 129734 \\
\hline N. of households & 11794 & 11794 & 11794 & 11794 \\
\hline N. of clusters & 320 & 123 & 74 & 41 \\
\hline
\end{tabular}

*** significant at $1 \%,{ }^{* *}$ at $5 \%,{ }^{*}$ at $10 \%$. Robust standard errors in brackets, clustered by municipality (by household in column (1)). All regressions weighted by EVS sampling weights and budget shares. Advertising defined as minutes per day (cf. Table 7). Number of municipalities: 1359 (1993), 1896 (1998). 


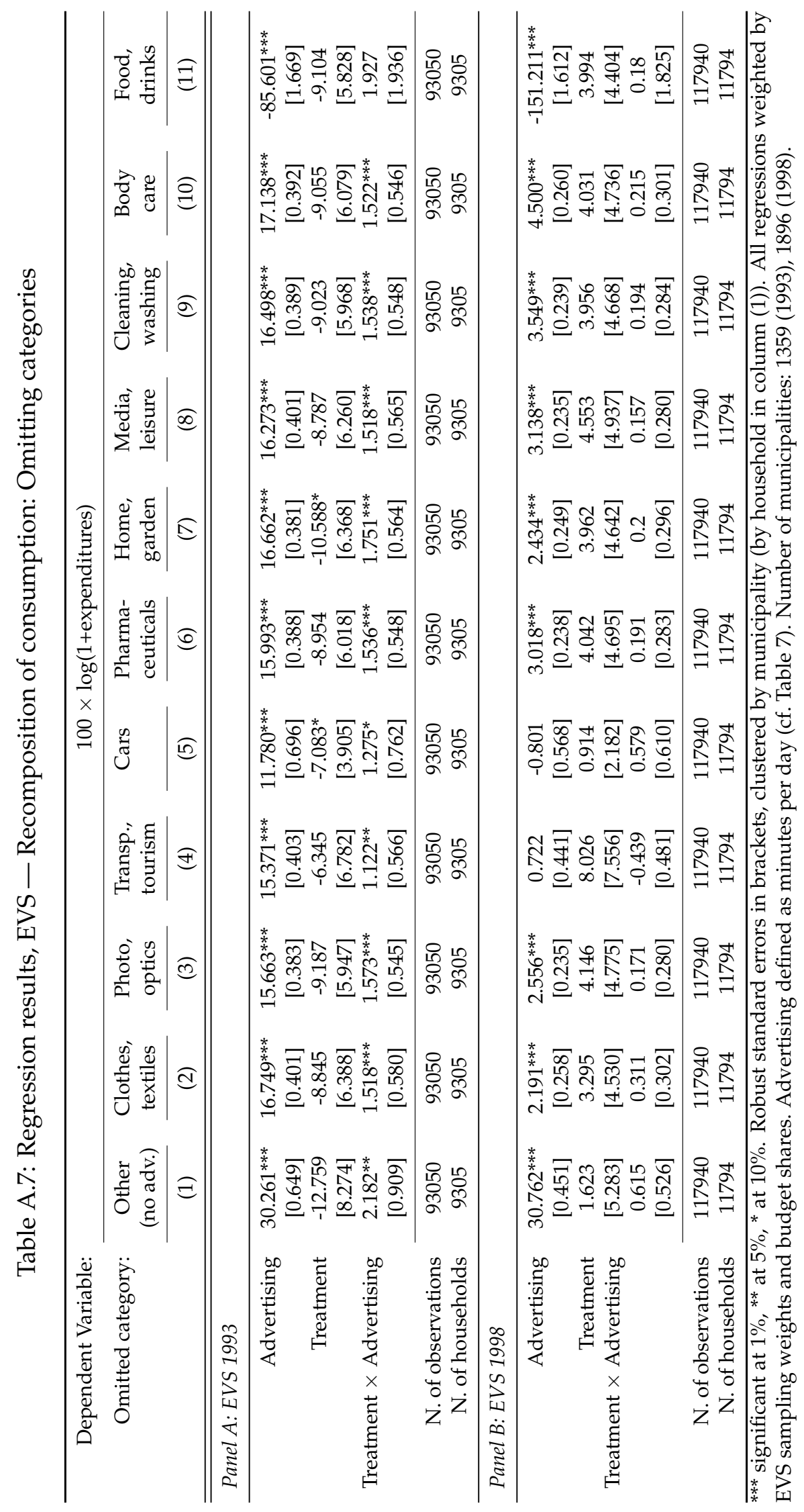




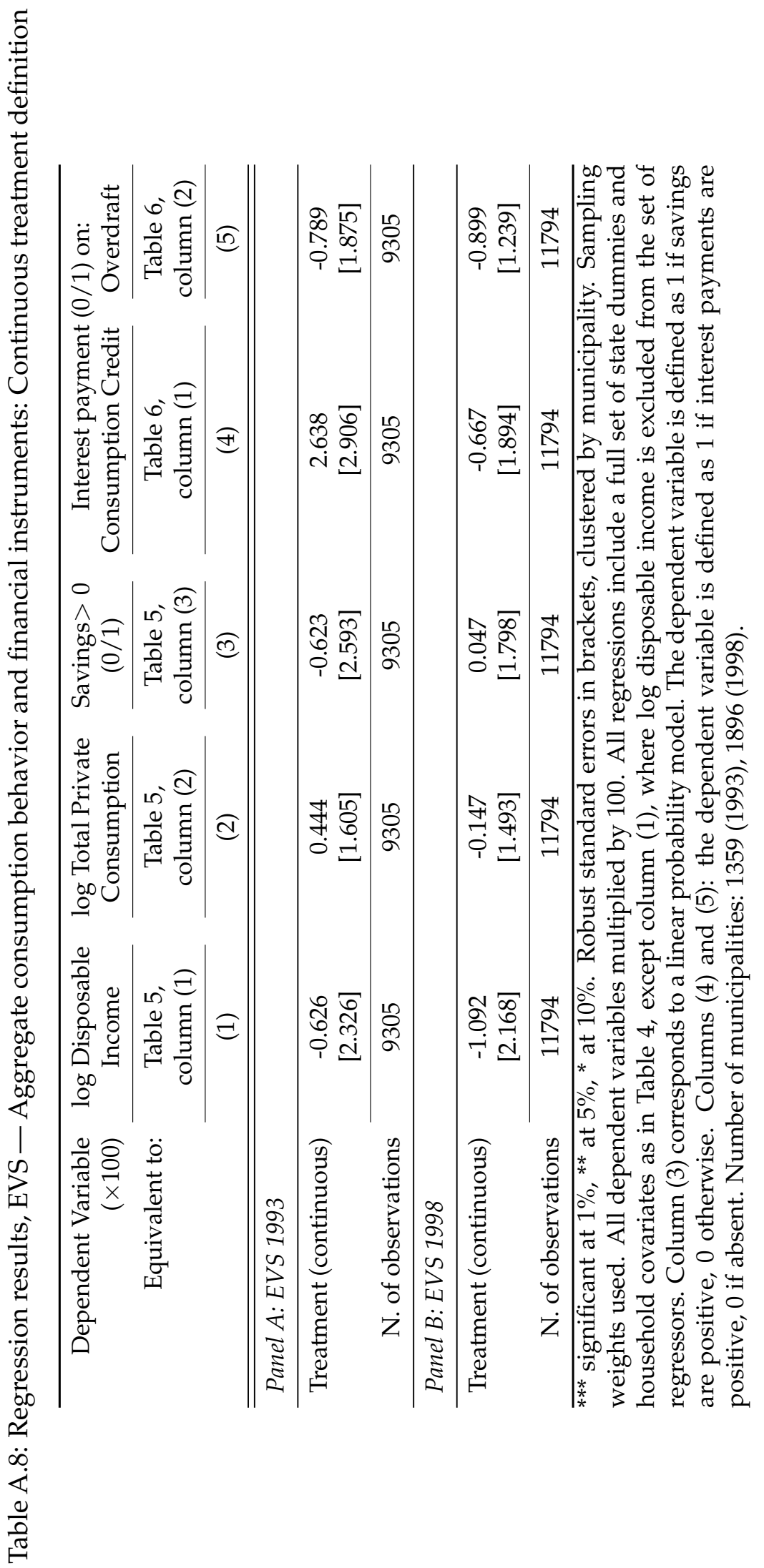




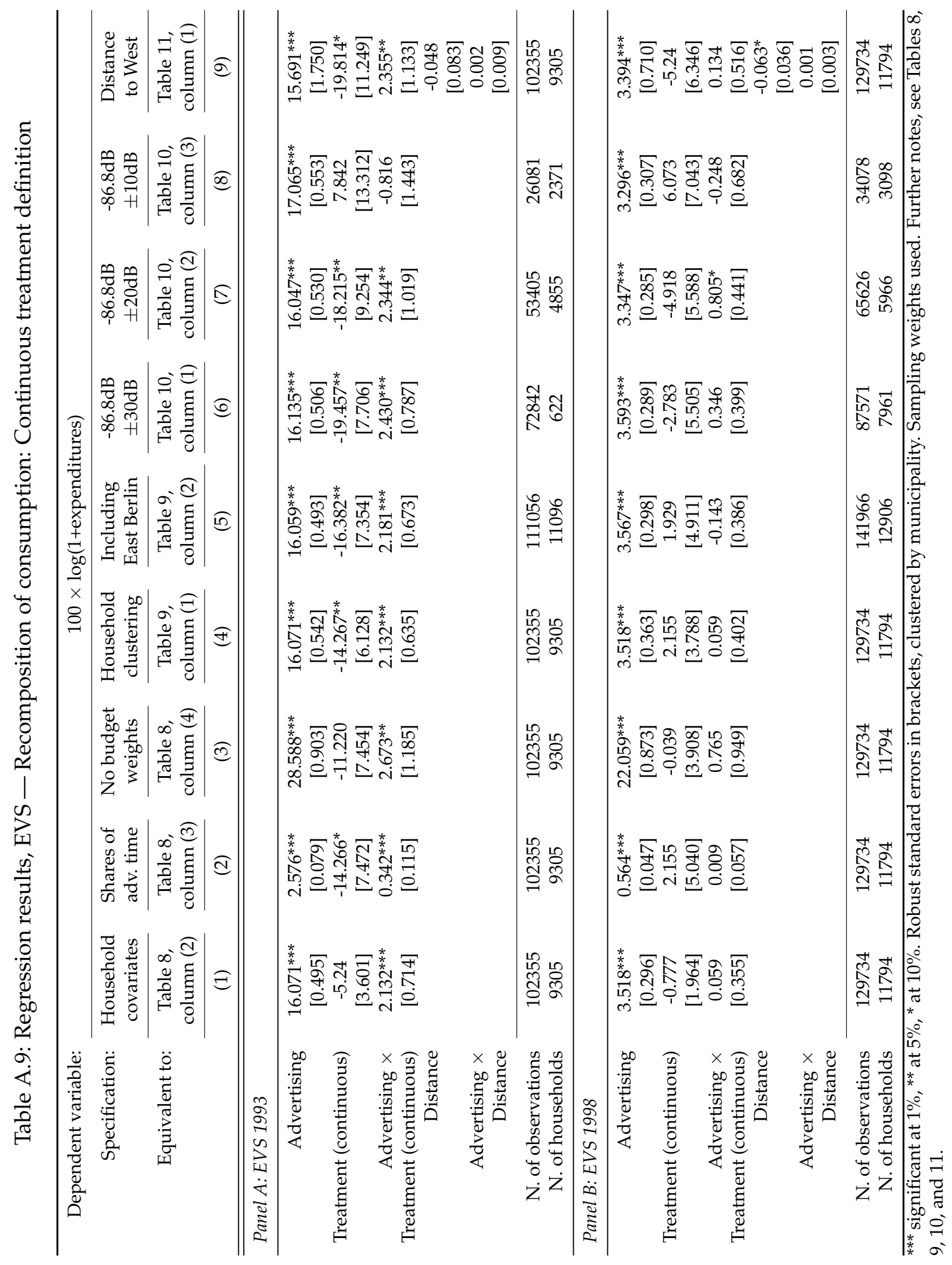




\section{A.6 Balancedness of covariates, EVS: Alternative samples}

Table A.10: Balancedness of covariates, EVS: Sample $-86.8 \pm 30 \mathrm{~dB}$

\begin{tabular}{|c|c|c|c|c|c|}
\hline Variable & Treatment & Control & Diff. & Std. Err. & p-value \\
\hline \multicolumn{6}{|l|}{ EVS 1993} \\
\hline Disposable Income & 41676.4 & 40341.7 & -1334.7 & 1062.6 & 0.209 \\
\hline Age & 47.9 & 49.8 & 1.9 & 1 & 0.071 \\
\hline N. of Children & 0.787 & 0.668 & -0.118 & 0.047 & 0.011 \\
\hline Single & 0.246 & 0.288 & 0.042 & 0.024 & 0.082 \\
\hline Female & 0.430 & 0.414 & -0.016 & 0.026 & 0.545 \\
\hline German & 0.998 & 0.995 & -0.003 & 0.002 & 0.172 \\
\hline Employed & 0.498 & 0.513 & 0.015 & 0.026 & 0.554 \\
\hline Retired & 0.248 & 0.269 & 0.021 & 0.025 & 0.389 \\
\hline On Welfare & 0.027 & 0.027 & 0.000 & 0.009 & 0.975 \\
\hline Small City (< 5000 inh.) & 0.190 & 0.215 & 0.026 & 0.021 & 0.225 \\
\hline \multicolumn{6}{|l|}{ Panel B: EVS 1998} \\
\hline Disposable Income & 12050.3 & 12150.2 & -99.9 & 287.6 & 0.728 \\
\hline Age & 52.7 & 51.7 & 1.0 & 0.8 & 0.217 \\
\hline N. of Children & 0.347 & 0.406 & -0.059 & 0.022 & 0.009 \\
\hline Single & 0.358 & 0.306 & 0.052 & 0.022 & 0.017 \\
\hline Female & 0.438 & 0.432 & 0.006 & 0.020 & 0.756 \\
\hline German & 0.999 & 0.993 & 0.005 & 0.002 & 0.002 \\
\hline Employed & 0.530 & 0.543 & -0.013 & 0.020 & 0.526 \\
\hline Retired & 0.363 & 0.351 & 0.013 & 0.021 & 0.536 \\
\hline On Welfare & 0.009 & 0.018 & -0.009 & 0.004 & 0.026 \\
\hline Small City (< 5000 inh.) & 0.174 & 0.231 & -0.058 & 0.014 & 0.000 \\
\hline
\end{tabular}

Total number of observations: 6622 in 1993 (5352 treatment, 1270 control), 7961 in 1998 (6314 treatment, 1647 control). 
Table A.11: Balancedness of covariates, EVS: Sample $-86.8 \pm 20 \mathrm{~dB}$

\begin{tabular}{|c|c|c|c|c|c|}
\hline Variable & Treatment & Control & Diff. & Std. Err. & $\mathrm{p}$-value \\
\hline \multicolumn{6}{|l|}{ Panel A: EVS 1993} \\
\hline Disposable Income & 40821.8 & 41747.6 & -925.8 & 1122.1 & 0.409 \\
\hline Age & 49.4 & 48 & 1.4 & 1.1 & 0.191 \\
\hline N. of Children & 0.691 & 0.780 & -0.089 & 0.049 & 0.067 \\
\hline Single & 0.275 & 0.248 & 0.027 & 0.026 & 0.299 \\
\hline Female & 0.401 & 0.431 & -0.030 & 0.027 & 0.276 \\
\hline German & 0.995 & 0.998 & -0.004 & 0.003 & 0.218 \\
\hline Employed & 0.534 & 0.501 & 0.033 & 0.028 & 0.232 \\
\hline Retired & 0.251 & 0.250 & 0.001 & 0.026 & 0.984 \\
\hline On Welfare & 0.025 & 0.028 & -0.003 & 0.009 & 0.773 \\
\hline Small City $(<5000$ inh.) & 0.228 & 0.192 & 0.037 & 0.022 & 0.103 \\
\hline \multicolumn{6}{|l|}{ Panel B: EVS 1998} \\
\hline Disposable Income & 48627 & 48313.8 & 313.2 & 1204.3 & 0.795 \\
\hline Age & 51.4 & 52.7 & -1.3 & 1.3 & 0.113 \\
\hline N. of Children & 0.422 & 0.346 & 0.076 & 0.059 & 0.001 \\
\hline Single & 0.296 & 0.359 & -0.064 & 0.032 & 0.005 \\
\hline Female & 0.433 & 0.439 & -0.006 & 0.034 & 0.777 \\
\hline German & 0.990 & 0.999 & -0.008 & 0.002 & 0.000 \\
\hline Employed & 0.553 & 0.530 & 0.023 & 0.034 & 0.278 \\
\hline Retired & 0.338 & 0.363 & -0.024 & 0.034 & 0.262 \\
\hline On Welfare & 0.017 & 0.009 & 0.008 & 0.010 & 0.052 \\
\hline Small City (< 5000 inh.) & 0.236 & 0.176 & 0.060 & 0.029 & 0.000 \\
\hline
\end{tabular}


Table A.12: Balancedness of covariates, EVS: Sample $-86.8 \pm 10 \mathrm{~dB}$

\begin{tabular}{|c|c|c|c|c|c|}
\hline Variable & Treatment & Control & Diff. & Std. Err. & $\mathrm{p}$-value \\
\hline \multicolumn{6}{|l|}{ Panel A: EVS 1993} \\
\hline Disposable Income & 42974.5 & 41764 & 1210.5 & 1380.8 & 0.381 \\
\hline Age & 49.4 & 47.8 & 1.6 & 1.3 & 0.227 \\
\hline N. of Children & 0.754 & 0.782 & -0.028 & 0.059 & 0.637 \\
\hline Single & 0.229 & 0.249 & -0.020 & 0.032 & 0.537 \\
\hline Female & 0.369 & 0.434 & -0.065 & 0.034 & 0.052 \\
\hline German & 0.997 & 0.998 & -0.001 & 0.002 & 0.547 \\
\hline Employed & 0.561 & 0.502 & 0.059 & 0.034 & 0.083 \\
\hline Retired & 0.265 & 0.248 & 0.017 & 0.034 & 0.614 \\
\hline On Welfare & 0.014 & 0.027 & -0.013 & 0.010 & 0.165 \\
\hline Small City (< 5000 inh.) & 0.315 & 0.190 & 0.126 & 0.029 & 0.000 \\
\hline \multicolumn{6}{|l|}{ Panel B: EVS 1998} \\
\hline Disposable Income & 51056.8 & 48249.6 & 2807.1 & 1497.9 & 0.061 \\
\hline Age & 51.6 & 52.6 & -1.0 & 1.3 & 0.357 \\
\hline N. of Children & 0.433 & 0.347 & 0.086 & 0.059 & 0.005 \\
\hline Single & 0.283 & 0.360 & -0.077 & 0.032 & 0.007 \\
\hline Female & 0.419 & 0.438 & -0.018 & 0.034 & 0.483 \\
\hline German & 0.998 & 0.999 & 0 & 0.002 & 0.850 \\
\hline Employed & 0.570 & 0.532 & 0.037 & 0.034 & 0.157 \\
\hline Retired & 0.343 & 0.358 & -0.015 & 0.034 & 0.582 \\
\hline On Welfare & 0.006 & 0.009 & -0.003 & 0.010 & 0.412 \\
\hline Small City (< 5000 inh.) & 0.319 & 0.172 & 0.147 & 0.029 & 0.000 \\
\hline
\end{tabular}

